\title{
TRADITIONAL ELECTRICITY SYSTEMS IN SPAIN: FENSA (1927-1991)*
}

JOSEAN GARRUÉS-IRURZUN

Universidad de Granada ${ }^{a}$

\begin{abstract}
Because the literature of European economic history has paid little attention to traditional electricity systems, the interest in studying Fensa lies in analysing the different types of companies, which helped to shape the development of the Spanish electricity sector prior to its present oligopolistic structure. This case provides insight into two issues. First, we learn about the behaviour of the second-generation companies (those that based their production on a controlled hydropower regime), which, despite their limited size, made their commercial specialisation (supplying the dynamic industrial market of Guipúzcoa) their main comparative advantage. Second, we analyse the behaviour of those companies which at this time, as distribution companies and/or subsidiaries of the large Spanish companies (Iberduero), were an instrument of the policy of integrating regional markets.
\end{abstract}

Keywords: micro-business history, regional and urban history, electric utilities, production, pricing, market structure

JEL Classification: N84, N94, L94, L11

* Received 14 April 2011. Accepted 31 March 2012. I am very grateful to the referees for their comments, which have truly helped improve the article. Financial support from the Economic History, Institutions and Development Research Group at the University of Granada (G08-SEJ-476) is gratefully acknowledged.

a Department of Theory and Economic History, Faculty of Economics and Business, University of Granada, Campus Cartuja s/n, 18071 Granada, Spain. jgarrues@ugr.es. 


\section{RESUMEN}

En un contexto historiográfico europeo que ha prestado poca atención a los sistemas eléctricos tradicionales (SET), el interés de estudiar Fensa reside en analizar los diferentes tipos de empresas que fueron configurando el desarrollo del sector eléctrico español antes de su actual estructura oligopolística. Este caso permite conocer, por un lado, el comportamiento de aquellas compañías de segunda generación -las que basaron su explotación en un régimen hidráulico regulado- que, a pesar de su limitado tamaño, hicieron de su especialización comercial (el abastecimiento del dinámico mercado industrial de Guipúzcoa) su principal ventaja comparativa. Y, por otro, analizar la actuación de aquellas firmas que se convirtieron, ya como distribuidoras y/o filiales de las grandes empresas españolas (Iberduero), en un instrumento de la política de integración de sus mercados regionales.

Palabras clave: historia empresarial, historia regional y urbana, empresas eléctricas, produccion, precios y estructura de mercado

\section{INTRODUCTION}

Little is known about the different business types present in the European electrical sector prior to the Second World War, despite the existence of excellent works. The history of the electricity industry has been centred on the foundation, growth and development of the most important companies. The main explanation is derived from the characteristics of the electricity industry itself. Since its beginnings, this sector has generally been considered as the business, which obtains the largest social and economic benefits, irrespective of the type of property or its territorial extension, when it is operated under a form of monopolistic industrial organisation based on vertical integration. In the last quarter of the $20^{\text {th }}$ century, however, nobody disputed, after the theoretical and empirical evidence gathered mainly in the 1970s in the United States, that the natural monopoly in the electricity sector was only relevant for transmission. Consequently, generation, distribution and commercialisation could be carried out in a competitive manner, either by a vertically integrated model or an unbundled model (Joskow and Schmanlensee 1983; Newbery 1999).

The existence of a transmission network, public or private, but common to a large extension of territory, favours the participation of small- and medium-sized operators, bringing into question one of the fundamental principles of the sector: the pre-eminence at all times, places and conditions of economies of scale, as well as the business strategies adopted by its largest companies (Hirsh 2001). 
This being the case, one of the questions that become relevant from the point of view of business history concerns the nature of the role of traditional electricity systems (TES) ${ }^{1}$ in the provision of an efficient electricity service before the appearance and consolidation of modern integrated electricity systems.

Although there are many important studies of large Spanish utilities before the Civil War, this picture becomes less clear when we start to consider the behaviour of the small- and medium-sized companies that made up the TES. Many authors have noted the importance small- and medium-sized companies had in the early stages of development of the Spanish electricity industry. There have been different strategies of analysis. Many studies in the field of business history have aimed at contextualising the beginnings of large companies, firms that in the medium and long term were more successful and were therefore the preferred object of study ${ }^{2}$. From the historical angle, many studies highlight the evolution of technological, economic and organisational characteristics prior to the construction of the regional and

1 By TES we understand a wide variety of types of companies that included small power stations that took advantage of some local feature right up to electricity companies with more complex connected networks for business but of a limited size and degree of integration between companies. From the chronological viewpoint, the TES, generally characterized by a predominance of medium-sized and small companies, were of unquestionable importance in the first 30 years of the development of the sector. This definition is not intended to be closed, but active and dynamic in order to better understand what preceded integrated electrical systems (IES). Therefore, it is a construct capable of improvement and adaptation to other economic and historical contexts.

2 Among others, Antolín (1989, 1996, 2006) and Garrués (1994) about Hidroeléctrica Ibérica; Cayón (1998, 2002), Aubanell (2000, 2005) and Tedde and Aubanell (2006) about Hidroeléctrica Española; Díaz Morlán (1998, 2006) about Saltos del Duero; Maluquer (1983) and Capel and Urteaga (1994) about Barcelona Traction; Bernal $(1993,1994)$ about Sevillana, Mengemor and Chorro; and Germán (1990) about ERZ. The only work about the history of the Spanish electricity sector as a whole before the Civil War in recent decades is the study by Bartolomé (2007). 
MAP 1

SPANISH HIGH-VOLTAGE TRANSMISSION GRID (1940)

$(100 \mathrm{kV})$

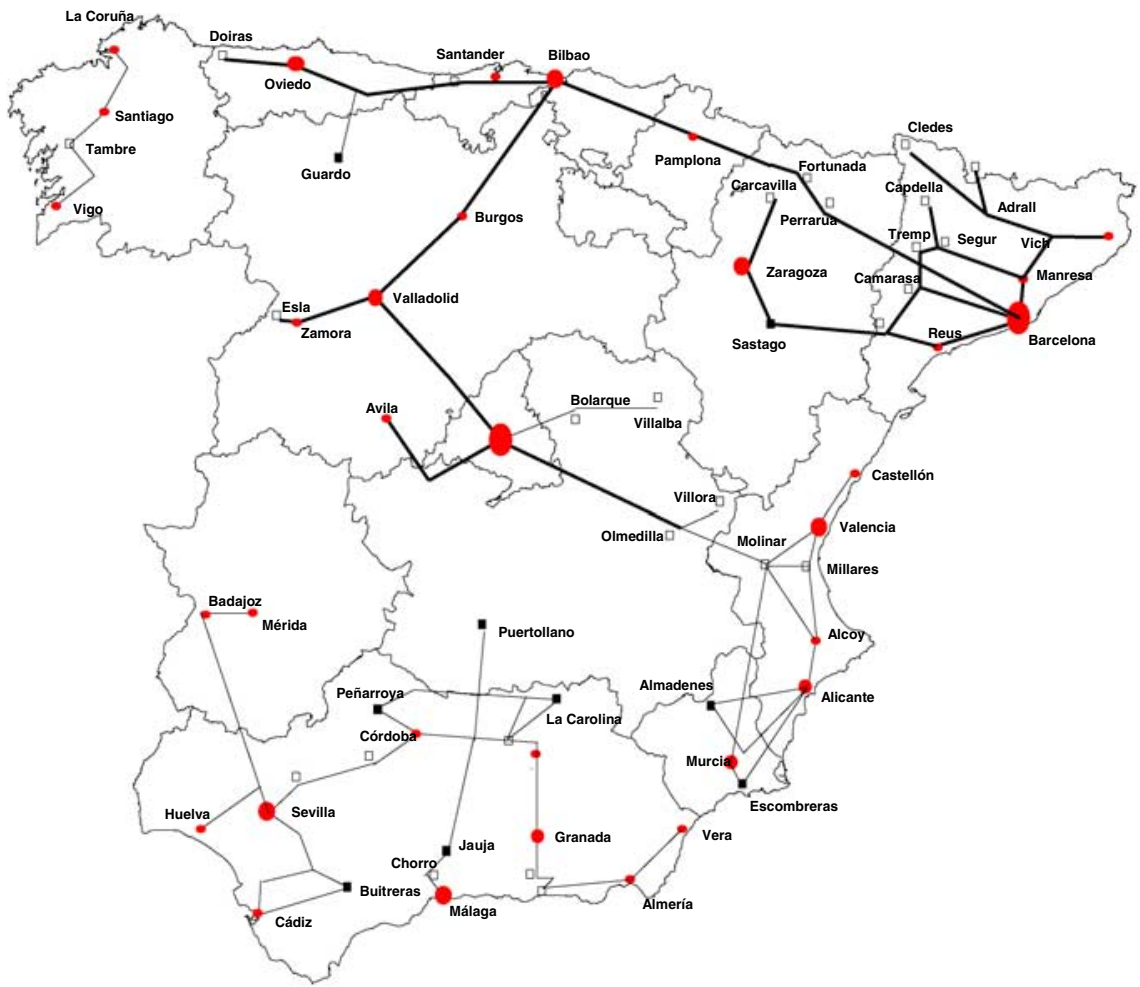

Source: Sirvent et al. (1960). Key: (—) Lines with voltage above $100 \mathrm{kV}$.

national electricity systems ${ }^{3}$. These analyses, especially in the last three decades, have brought our knowledge up to the level of other European countries. There are, of course, some fields in which the historiography has grown less in relation to TES. For this reason, from the business history point of view, this article proposes the application of the case study to the medium-sized and small utilities. Assessing their production, commercial and financial strategies helps us, when we have a sufficient critical mass of works, to build a clearer picture of our diverse and complex industrial past and its impact on the present.

The desirability of exploring the TES does not imply that the starting point of this article includes an aprioristic idea about the advantage of this

3 See, for example, Amigo (1989, 1992), Germán (1990), Maluquer (1992), Aubanell (1992), Núñez (1994, 1995, 1997), Garrués (1996, 1997, 2006a and 2006b), Carmona (1999), and Hidalgo (2012). 
TABLE 1

THE SPANISH TES IN COMPARISON WITH THE FIRST RIS IN 1949

\begin{tabular}{|c|c|c|c|c|c|c|c|c|c|c|}
\hline & \multirow[t]{2}{*}{ Electricity Systems } & \multicolumn{3}{|c|}{ Production } & \multicolumn{2}{|c|}{$\begin{array}{c}\text { Direct } \\
\text { distribution* }\end{array}$} & \multicolumn{2}{|c|}{ Companies } & \multicolumn{2}{|c|}{ RIS leadership** } \\
\hline & & ES & TES & TES/ES & TES & RIS & TES & RIS & Companies & $\begin{array}{c}\text { Electricity distributed } \\
\text { in RIS }\end{array}$ \\
\hline & & \multicolumn{5}{|c|}{$\%$} & \multicolumn{2}{|c|}{ Number } & & $\%$ \\
\hline & & A & $\mathrm{B}$ & $\mathrm{C}=\mathrm{B}: \mathrm{A}$ & $\mathrm{D}$ & $\mathrm{E}$ & $\mathrm{F}$ & G & $\mathrm{H}$ & I \\
\hline 1. & Iberduero & 25 & 33 & 29 & 87 & 65 & 193 & 26 & Iberduero & 69 \\
\hline 2. & Hidrola & 22 & 35 & 34 & 83 & 52 & 87 & 7 & Hidrola & 70 \\
\hline 3. & Galicia & 4 & 6 & 29 & 96 & 81 & 42 & 7 & Gallega de Electricidad & 75 \\
\hline 4. & Asturias-Cantabria & 12 & 3 & 6 & 96 & 78 & 39 & 12 & Viesgo; Hidrocantábrico & 62 \\
\hline 5. & Andalusia & 11 & 12 & 24 & 89 & 93 & 45 & 12 & Sevillana; Mengemor; Chorro. & 94 \\
\hline 6. & Catalonia & 21 & 3 & 3 & 90 & 72 & 17 & 16 & $\begin{array}{l}\text { Barcelona Traction; Fluido } \\
\text { Eléctrico }\end{array}$ & 70 \\
\hline 7. & Aragón & 5 & 9 & 41 & 91 & 72 & 46 & 6 & ERZ & 67 \\
\hline & Spain & 100 & 100 & 22 & 87 & 70 & 469 & 86 & 33 & 95 \\
\hline
\end{tabular}

TES: traditional electricity systems; RIS: regional integrated systems; ES: electricity system.

Note: *The rest of the distribution was carried out by other companies; **Companies with more than 20 GWh of the electricity distributed.

Source: Own compilation from Sindicato de Aguas, Gas y Electricidad (1949). 
model of business compared with large firms and/or the first IES. Furthermore, as this study shows, it is not easy to identify clear lines of division between the strategies associated with either system. Although the differences of scale, co-ordination and information of the IES firms always gave them a capacity to act which was beyond the scope of those linked to the TES, the level of adaptive efficiency of each company should be studied in its historical and economic context ${ }^{4}$.

For this reason, the interest in analysing Fuerzas Eléctricas de Navarra $(\text { Fens } a)^{5}$ lies in enriching the panorama outlined so far of the different types of companies that participated in the development of the Spanish electricity industry prior to its current oligopolistic structure and, in particular, the transition from what are referred to as TES to integrated systems. In this sense, referring to Navarra, if the studies of Arteta and Irati were representative of those pioneering companies that, thanks to their economies of diversification, were able to survive the growing maturity of the markets (Garrués 2006a and 2006b), this study of Fensa will allow us to examine two other interesting issues. First, to learn about the behaviour of the second-generation companies, those that based their business on a controlled hydropower regime, and which had as their main competitive advantage their commercial specialisation (supplying the dynamic industrial market of Guipúzcoa). Second, to analyse the performance of those companies that became, whether as distributors or subsidiaries of the great companies in the country (Iberduero, from 1946), an instrument of the policy of integration of regional markets (e.g. Navarra).

All of these matters are developed in different sections. Section 2 deals with the birth of Fensa, as well as its productive and commercial strategy, with particular attention to its pricing policy. Section 3 looks at Fensa's behaviour in the Guipúzcoa market and its relations with two of the largest companies in the country (Saltos del Duero and Hidroeléctrica Ibérica). In Section 4 the company's economic-financial development is evaluated. Section 5 describes its instrumental function, as a subsidiary of Iberduero, after 1946. Finally, the last part will summarise the main points of the paper.

\section{THE BIRTH OF A SECOND-GENERATION COMPANY: PRODUCTION AND COMMERCIAL STRATEGY}

The second phase of industrial electrification, from the technological viewpoint, came about due to the innovations derived from electricity transmission over medium and long distances. These allowed the businesses

\footnotetext{
4 From the point of view of dynamic and evolutionary efficiency, understood as adaptive, see North (1990).

5 The primary sources are collected at the end of the paper under the title of Sources and a more detailed account is given in Garrués (1996, pp. 667-758 and pp. 1011-1060).
} 
to benefit from economies of location, scale and scope, which facilitated the use of the most appropriate local hydro resources, as well as the exploitation of the large descents existing in mountain ranges and also the small gradients of large rivers.

Although the advantages of high-voltage power supplies have been known since 1883, the transmission of large amounts of power over long distances took several decades to become widespread (Hausman et al. 2008). Its economic viability only came about once it was technically possible to build large dams to control the flow. With these dams it became feasible for the first time to take full advantage of economies of scale in generation, as long as the increase in minimum flow and its control allowed the extension of constant annual energy contracts and reduced the overruns caused by the low load of some plants. The reduction of generation costs associated with the increase in size of production units, benefited from the widening of the market due to the improvement of production resources, the quality of service and also, in some cases, the costs. Additionally, this decrease in costs increased the range of profitability of electricity transmission and opened up new possibilities for the interconnection of systems.

In 1926, the engineer Víctor Urrutia indicated that the most common type of dam was a diversion dam and channel length, without large reservoirs (run-of-the-river power plants; Urrutia 1926). This delay between learning about the transmission of electricity at high voltage and the technology becoming widespread, given a sufficiently large potential demand, can be explained in the case of Spain by the concurrence of a number of different factors ${ }^{6}$. The waterfalls were a long distance from the points of consumption, which substantially increased the costs involved in dam projects. Private business, which in some cases were able to convince Spanish and/or international sources of finance of the advantages of participating in the larger scale business (Díaz Morlán 1998, 2006; Valdaliso 2006), did not receive much economic support from the Spanish Administration (Maluquer 2006, pp. 61-76; Bartolomé 2011). However, the main restriction was technologically economic. Large dams underwent a spectacular development once the new possibilities of the use of reinforced concrete became more widely known, due to its greater safety, versatility and economy, now supported by a theoretical basis that complemented the traditional empirical method. This coincided with the growing process of mechanisation in construction, in part due to the increased labour costs that occurred during the First World War and also the important development of the internal combustible engine.

In this technological and economic context, Fensa was established in February 1927, with a share capital of 3 million pesetas, with the object of

${ }^{6}$ Bartolomé (2005) clearly explained many of these reasons when analysing the failed attempt to establish a national network and, as a result, the delay in the integration of the Spanish regional electricity markets. 
producing and distributing electricity from the exploitation of the River Salado reservoir. This meant the technical, financial and managerial relaunch of Hidroeléctrica de Alloz, a failed business venture, which in 1916 had tried to develop a project designed by the engineer Emilio Azarola.

From a technical point of view, Fensa decided to expand the capacity of the reservoir of Alloz (to $83.5 \mathrm{hm}^{3}$ ) to exploit the high-load peaks during times of low water level, because there was no waterfall in the province of Guipúzcoa that could provide these supplies. The torrential character of the River Salado and the natural narrowing at the Peñas de Tarrabia made this an ideal site for constructing a hydroelectric dam. The decisions to build a dome dam (one of the thinnest in Europe for its height) and develop the hydropower resources were taken by a team of highly qualified engineers ${ }^{7}$. The construction of the reservoir of Alloz was the result of a consortium between Confederación Hidrográfica del Ebro and Fensa, from which both benefited. While the former company solved its serious problem of low water levels in the upper River Ebro $(28,000 \mathrm{ha})$, the latter succeeded in becoming the best controller of electricity in the poorly base load-supplied industrial market of Guipúzcoa ${ }^{8}$.

As for the financial aspect, Fensa, in contrast to what had happened to its predecessor, was able to count on the support of a more varied and solid managerial and shareholding group. Its share capital was subscribed by members of the local upper and middle classes, which, coming from different socioprofessional and political backgrounds, were very active in the setting up of the most important electricity company in the province. All the same, in its early days Fensa behaved like a family company. The founding partners were at the same time its most important promoters, main shareholders and most prominent managers. With the passing of the years, the economic needs of the company made it necessary for new capital to be incorporated, including finance capital, and also for there to be changes in its board of directors, meaning that the management of the company was ever more distant from the ownership. Even so, control over the company was retained by the circle of the founders' family members, who were also very active in the setting up of other local industries?

The inauguration of the reservoir of Alloz and its hydropower station $(6,800 \mathrm{~kW})$ took place on July 24, 1930. The rapid expansion of Fensa's electricity sales in the Guipúzcoa market was due to the production availability of its summer water flow regime and due to the low cost of its constant supply once the lack of power during winter was complemented by electricity

\footnotetext{
${ }^{7}$ Among them we can highlight the advisor for the dam, Grunner and Orbegozo, one of the engineers who played an important role in Spanish hydropower development.

8 Errandonea (1931). In accordance with Spanish water policy (Bartolomé 2011), the state's economic contribution to dam construction was not substantial, and in fact was lower than that set by law. The company received only 15.4 per cent of the total budget (estimated to have been over 7 million pesetas).

9 To see the list of board of directors, shareholders and their participation in other industrial activities, see Garrués (1996).
} 
bought from other companies in the south of the province (Eléctrica Carcar and Eléctrica Recajo). The new demand for a constant supply made it necessary for Fensa to buy larger amounts of electricity from other companies each year (Compañía Hidráulica de Sumbilla in 1932 and Electra Puente Marin and Electra Aranaz in 1940), and even to buy two waterfalls in the north of Navarra (in 1937). Thus, whilst the energy purchased between 1932 and 1936 was 20 per cent of the distributed production during the Civil War, the figure increased to 36 per cent, reaching its highest value during the 1943 drought at 70 per cent (Appendix 1). Fensa was transformed from a mere producer, boosted by strong demand from its new customers, into an integrated producer-distributor purchasing surplus power from other mediumsized companies through long-term agreements ${ }^{10}$. In order to rationalise its activity, Fensa created two subsidiary companies (Saltos de Ituren, 1937 and Eléctrica Aritzacun, 1940) through which it organised high-voltage distribution in the valley of Oria and low-voltage distribution in San Sebastián.

Fensa's predilection for the Guipúzcoa market was also conditioned by the fact that the attempt carried out in 1933 to supply the capital of Navarra, through the company Electra Pamplona, had to be stopped because of other companies that operated in the Pamplona cartel (Arteta and Irati) ${ }^{11}$.

The increasing demand for electricity led the company's directors to study the construction of a new hydropower station. Although the company had at its disposal a large number of the administrative concessions along the River Salado, the construction of the new waterfall (Mañeru) brought with it many problems. In 1936, Fensa, while drawing up a contract for the exchange of electricity with its main competitor in the Guipúzcoa market (Ibérica), set out amongst its conditions that there was «no obstacle of any type to the construction of this when the Fuerzas Eléctricas de Navarra deem it to be convenient» ${ }^{12}$. The reason behind this condition lay in the restriction on Ibérica, stemming from its agreement with Saltos del Duero $(1934)^{13}$, in the event of it trying to increase its production facilities. Although this fact initially had a major effect on Iberica's means of production, the spirit of the

10 This is not peculiar to medium-sized enterprises. Ibérica, to a lesser extent, suffered a similar process after signing the agreement with Saltos.

11 The defensive behaviour of Irati and Arteta against Electra Pamplona, buying energy from Fensa, is understandable considering that the new productive superiority of Pamplona could break the relatively stable cartel formed by the first three companies after 1916. The price that Irati y Arteta paid, given the production and financially weakened position of Pamplona in those years, was used by Ibérica, through a supply agreement signed in 1933 with Electra Pamplona, to enter the Pamplona market (Garrués 2006a and 2006b).

12 Records of Fensa's Board of Directors (from now on RFBD), 29/05/1936, p. 61 and RFBD, 26/ 03/1936, p. 60.

13 On the agreement between Saltos del Duero and the Hydro Group, signed 2 years later, in February 1936, see Díaz Morlán (2006, pp. 294-311). This author provides a clear explanation of the Duero business context and its effects on the development of the Spanish electricity sector. Reading these pages is extremely helpful to fully understand Section 3 of this article. 
FIGURE 1

EVOLUTION OF ELECTRICITY DISTRIBUTED AND CONSUMED IN FENSA'S MARKET (1930-1946)

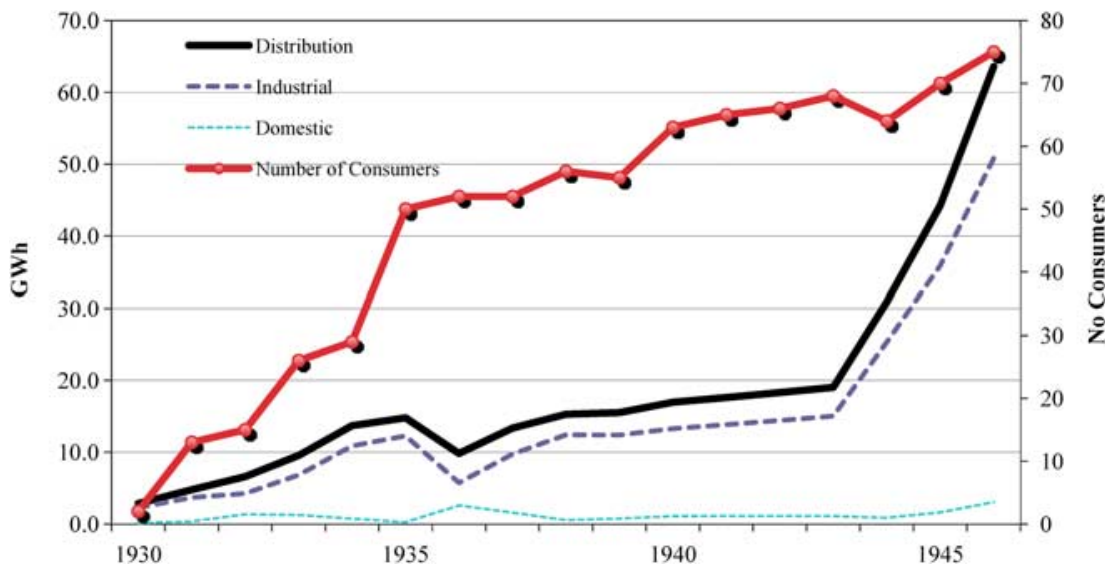

Source: Appendix 1.

agreement would be broken if the company improved its resources through agreements with other companies. All of this, obviously, meant that it depended on the approval of Saltos del Duero.

Another hindrance to the quick construction of the waterfall was the Civil War. Once the war was over the problems in importing equipment from the countries now involved in the Second World War, and the problems of postwar supply shortages affecting Spanish industry became a real headache for the company's board of directors. In fact, the Mañeru hydropower station came on line at the end of August 1944, 3.5 years later than planned. What is more, the low quality of the materials used initially reduced its theoretical capacity of $4,800 \mathrm{~kW}$.

Fensa's strong commercial specialisation, based on satisfying the energy demands of industrial businesses, explains the minimal contribution of domestic consumption, and, in turn, the strong correlation that existed between industrial consumption and total consumption (Figure 1). The greater relative importance of domestic consumption in the early years was due to the fact that the company had not managed to set up the technical infrastructure necessary to be able to sell all of its production in the Guipúzcoa market. In addition, in the first year of the Civil War, according to its board of directors, "the industrial area of Guipúzcoa was under the tyranny of the Reds", and its supplies were switched off ${ }^{14}$. This meant that during this

14 Records of Fensa's General Shareholders' Meeting (from now on RFGM), 31/03/1937, pp. 31-32. 
time a large part of the electricity was directed, through small distributors, to the domestic market in Navarra. Even so, the growth in industrial consumption in the first period (1930-1935) was spectacular. Whilst in 1930 the figure was $2.4 \mathrm{GWh}$, by 1935 this had gone up to $12.5 \mathrm{GWh}$, with only fifty clients. The company's sudden takeoff came about because of the high demand for electricity among its clients in Guipúzcoa. In fact, the rapid sale of its energy led it to buy electricity from third parties in 1932. The first clients before the Civil War were large- and medium-sized energy consumers, cement factories, paper firms and electricity companies.

The diversion of part of the production to the Navarra market and the supply of electricity to the war industry in Guipúzcoa, and to a lesser extent Vizcaya, once these provinces had come under nationalist rebel control, explains why the decrease in consumption during the period of the war was not greater. Between 1937 and 1943 consumption went up to $4.8 \mathrm{GWh}$, mainly due to greater demand from its subsidiary Electra Aritzacun.

The low level of growth of consumption in relation to demand during this second phase was also connected to Fensa's limited production capacity. However, its efforts to expand its supply through new interconnections and the setting up of subsidiaries did not prevent the first setback, the drought of 1942, from forcing the company to buy energy mainly from Electra Puente Marin, Saltos de Ituren and Electra Carcar. The situation became even worse the following year, when its own production was limited to 68 per cent of the average annual production. Actually, the crisis merely came early in a year when the restrictions affected the whole of the Spanish electricity sector (Sudrià 1987; Díaz Morlán and San Román 2009).

In Fensa's final years as an independent company (1943-1946), consumption grew by $37.8 \mathrm{GWh}$, in large part due to the fact that the Mañeru waterfall began production in 1944, and to a lesser extent, because of the help received from its now parent undertaking, Iberduero (the successor to Ibérica). Along with the new customers, the clients who benefited most from the Navarra company's electricity were Cementos Rezola, Juan Echezarreta, Papelera de Aralar and Algodonera San Antonio.

Once the main lines of supply had been established, Fensa completed its portfolio with medium-sized and small clients. However, the distribution of industrial consumption in the 1930s was highly concentrated. The cement sector (31 per cent), the paper sector (27 per cent) and the electricity sector (24 per cent) were those that benefited most from Fensa's electricity ${ }^{15}$. In the early-1940s certain activities started to lose importance due to the establishment of new industries, Fensa's production limitations and greater competition from the electricity companies of Guipúzcoa. In short, from the

15 Obviously, the evolution was not linear. In 1932 the electricity consumption of the utilities was 8.6 per cent of the total consumption, 3 years later this represented 27.2 per cent and in 1944 it had increased to 32.6 per cent. 
point of view of inputs, Fensa went from being a producer to a producerdistributor. As with Ibérica or Hidrola its function was producing and transporting electricity to large- and medium-sized customers through long-run contracts, because the distribution task was delegated to its two subsidiaries ${ }^{16}$.

The rapid growth of Fensa in the Guipúzcoa market was not so much due to a situation of expansion in the industry ${ }^{17}$, but rather due to the structural deficiencies of the electricity system in facing the processes of urbanisation and industrialisation (Garrués 1994, pp. 198-209). The electricity market of Guipúzcoa, the highest per capita electricity consumption in Spain at that time, was supplied by a traditional electrical system that was highly decentralised and poorly integrated in comparison with the highly concentrated Vizcaya model based around Ibérica. In fact, knowing the weakness of market penetration of Iberica $^{18}$, which supplied a third of the electricity consumed in Guipúzcoa through a small number of large customers and several subsidiaries, the rest of the consumption was based on the production of many small local utilities and various types of auto-producers, as well as the energy acquired in the northern province of Navarra (Garrués 1997, chapter 3). In a context where the potential demand exceeded the production capacity, the Alloz reservoir had important strategic value. This allowed the company to maintain a constant supply of energy throughout the year, but especially during summer and autumn ${ }^{19}$.

What was the role played by industrial prices in the commercial policy of the company?

The evolution of Fensa's average prices did not vary greatly, always being between 8.6 and 9.4 cents of a peseta per kWh, except between 1941-1942. The evolution of its industrial prices $(\sim 2$ or 3 cents less than its domestic prices), given the importance of industrial consumption within its total consumption, was in line with that described (Table 2).

Fensa offered widely differing rates to its clients. The company offered better rates to the major consumers than to the small- and medium-sized consumers, whose prices in the worst cases were above 20 cents/kWh (Table 3 ). With the passing of time there were also modifications to prices within the same type. If we exclude the customer type with the highest consumption (which had

16 In relation to Ibérica's concentration of consumption and the type of clients, see Antolín (1996, pp. 241-244). Regarding Hidrola, see Aubanell (2000, pp. 162-163) and Tedde and Aubanell (2006, pp. 197-200).

17 In the latter sense, the industry of Guipúzcoa did not enjoy one of its better periods. In fact, the most important sectors of Guipúzcoa industry, those of paper and metal, noted a marked decrease in the rate of growth since the mid-1920s.

18 The Technical Record of the Five Year Period (1940), elaborated by Ibérica, is very clear. The average consumption between 1935 and 1939 shows that Ibérica's participation in the Basque Country was the following: Vizcaya (75.4 per cent), Guipúzcoa (21.5 per cent), Alava (2 per cent) and Navarra (1 per cent). Ibérica at that time controlled only 38 per cent of consumption in Guipúzcoa (Garrués 1994).

${ }_{19}$ Periods when the electricity companies and auto-producers had most problems with their production due to the low water levels in the local rivers. 
TABLE 2

THE EVOLUTION OF FENSA'S AVERAGE SALE PRICES (1930-1946) (Cents/KWh)

\begin{tabular}{|c|c|c|c|c|c|c|c|}
\hline Year & Industrial & Domestic & Average & Year & Industrial & Domestic & Average \\
\hline 1930 & 8.8 & & 8.8 & 1939 & 9.1 & 11.3 & 9.2 \\
\hline 1931 & 8.2 & 12.3 & 8.6 & 1940 & 8.5 & 11.9 & 8.8 \\
\hline 1932 & 8.4 & 11.9 & 9.3 & 1941 & & & 10.3 \\
\hline 1933 & 8.8 & 11.3 & 9.2 & 1942 & & & 10.2 \\
\hline 1934 & 9.1 & 11.1 & 9.2 & 1943 & 8.6 & 11.6 & 8.8 \\
\hline 1935 & 8.6 & 11.9 & 8.6 & 1944 & 8.9 & 11.5 & 9.0 \\
\hline 1936 & 8.9 & 12.2 & 9.4 & 1945 & 8.0 & 12.2 & 8.2 \\
\hline 1937 & 8.6 & 11.6 & 9.0 & 1946 & 7.7 & 13.1 & 8.0 \\
\hline 1938 & 8.7 & 11.4 & 8.8 & & & & \\
\hline
\end{tabular}

Source: Own compilation from consulting monthly entries in the General Ledger of Fensa (1927-1946) and the Annual Reports of Fensa (1930-1946).

TABLE 3

THE DISTRIBUTION OF FENSA'S AVERAGE INDUSTRIAL PRICES ACCORDING TO DIFFERENT TYPES OF CONSUMPTION (1933-1943)

(Cents/KWh)

\begin{tabular}{|l|c|c|c|c|c|c|c|}
\hline & A & B & C & D & E & F & Average \\
\hline 1933 & 8.5 & & 8.6 & 10.4 & 11.4 & 21.9 & 8.8 \\
\hline 1936 & 3.0 & 8.2 & 9.1 & 12.5 & 14.7 & 23.3 & 8.9 \\
\hline 1939 & 6.2 & 10.4 & 12.3 & 11.7 & 18.4 & 26.9 & 9.1 \\
\hline 1943 & 7.0 & & 11.3 & 13.5 & 15.7 & 23.7 & 8.6 \\
\hline
\end{tabular}

Source: as Table 2

Key: A: >1,000,001 kWh; B: 500,001-1,000,000; C: 100,001-500,000; D: 50,001-100,000; E: 10,00150,000; and F: 1-10,000.

a reduction in price), and that with the lowest consumption (which had an increase of 7 per cent), the other types saw their prices rise between 1933 and 1943 by more than 23 per cent.

If we take the analysis to a more detailed level, which relates the price and consumption for each client, we can highlight two facts (Figure 2). First of all, during the early years there was no strong relationship between the two variables, some companies received lower prices than others with a higher level of consumption. Therefore, along with the relationship of the lower 
FIGURE 2

PRICES PAID BY FENSA'S INDUSTRIAL CLIENTS (1933 AND 1943)

(Cents and GWh)
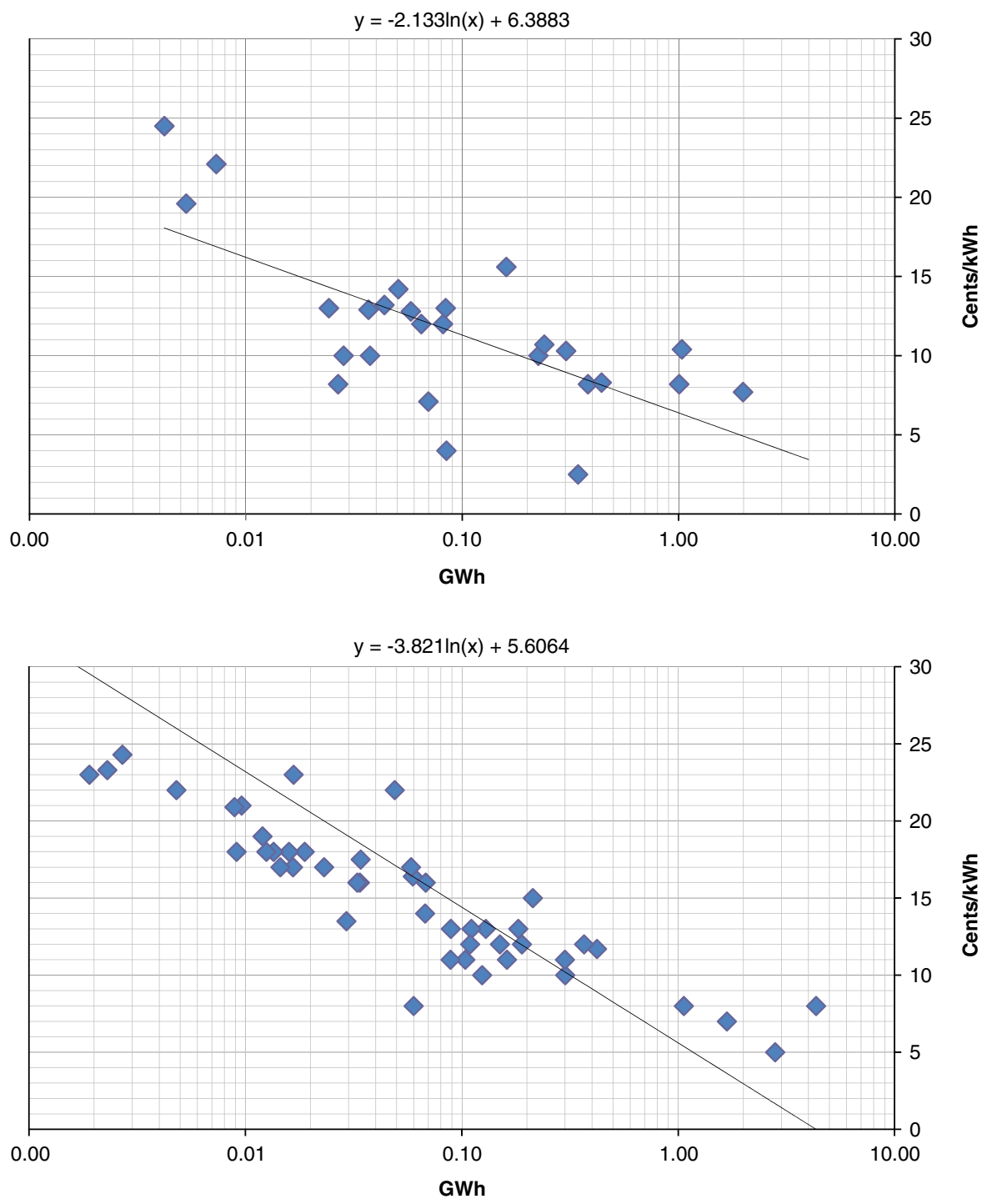

Source: see Table 2. 
rates to the greater consumers, other parameters need to be included. This is not strange if one remembers that Fensa wished to gain entry into markets that were competitive. The exclusivity of supply, the distance of the point of consumption from the site of production, the negotiating abilities of the agents and the prices offered by potential competitors, all had a lot to do with rates. The second aspect is that, once the distortions in average prices caused by the Civil War had been eliminated and Fensa's market had been defined, it was from 1943 onwards that it can be proven that rates were set mainly according to consumption levels rather than any other consideration. In fact, the companies that obtained the best prices (below 10 cents/kWh) were the cement factories, the electricity distributors and the paper companies, followed by a fairly small group of medium-sized clients (between 300 and $500 \mathrm{MWh}$ ), who paid between 10 and 12 cents/ $\mathrm{kW}$ consumed. The vast majority of companies with low levels of consumption paid prices above 12 cents.

Another criterion that influenced price decisions was the seasonal nature of consumption. Fensa undercut the main market rates in periods of scarcity in summer and hours of high consumption and, to a lesser extent, for supplies dispatched in winter and off-peak hours ${ }^{20}$.

In short, Fensa's pricing policy varied essentially in relation to certain aspects: (a) the total power contracted; (b) consumption; (c) the time of year, summer or winter; (d) the prices offered by other competing companies; (e) the unit profit necessary to cover costs, remunerate capital and carry out an adequate policy of repayments and investments. At the moment the absence of accurate information does not reveal the exact importance of these variables in the negotiations to set Fensa's selling prices and their renewal. However, in general, the electricity demand-charge rate structure ( $\mathrm{a}$ and $\mathrm{b}$ variables cited) became, as happened in the United States with the industrial and large commercial customers, the principal criteria used to establish rates and introduce the principles of price discrimination. This policy was the second-best form of peak-load pricing and, certainly, was not carried out with the rates used for light and household uses (Neufeld 1987) ${ }^{21}$. In this type of consumption, where Fensa remained increasingly in competition with Ibérica and other companies, the main price discrimination criteria was to set rates below those offered by competitors $(d)^{22}$.

There are two differences between Fensa's average prices in comparison with those of Irati and Arteta, two important Navarra companies (Table 4). The first is the relative stability of Fensa's prices throughout the period.

${ }^{20}$ For example, Portland and Rezola had to pay for winter power at 3 or 4 cents/kWh, respectively, and summer power at 9 cents/kWh.

21 A clear and comprehensive explanation of the «electricity demand-charge rate structure» and its implementation in Spain can be seen in Antolín (1988).

${ }^{22}$ In the industrial market, except for several large consumers, Ibérica's interest in competing with Fensa must have been very weak. Among other reasons, because Ibérica would incur a high opportunity cost establishing the necessary infrastructure to distribute electricity to places that were relatively remote, disperse and with a complicated orography. 
TABLE 4

IBÉRICA, IRATI AND FENSA PRICES ACCORDING TO DIFFERENT TYPES OF CONSUMPTION

(Cents/kWh and \% of consumption)

\begin{tabular}{|c|c|c|c|c|c|c|}
\hline & \multicolumn{2}{|c|}{ Ibérica } & \multicolumn{2}{|c|}{ Irati } & \multicolumn{2}{|c|}{ Fensa } \\
\hline & 1935 & & 1937 & & 1935 & \\
\hline & $\begin{array}{l}\text { Cents/ } \\
\text { kWh }\end{array}$ & $\%$ & $\begin{array}{l}\text { Cents/ } \\
\text { kWh }\end{array}$ & $\%$ & $\begin{array}{l}\text { Cents/ } \\
\text { kWh }\end{array}$ & $\%$ \\
\hline Low-voltage & 30.1 & 13.3 & 26.2 & 28.3 & 11.9 & 0.7 \\
\hline Lighting and domestic uses & 42.5 & 6.7 & 34.8 & 12.6 & & \\
\hline Public & 23.7 & 1.4 & & & & \\
\hline Residential & 59.8 & 2.9 & & & & \\
\hline Fixed-base rates & 33.6 & 1.8 & & & & \\
\hline Domestic uses & 30.0 & 0.5 & & & & \\
\hline Industrial & 17.6 & 6.6 & 15.0 & 15.7 & 11.9 & 0.7 \\
\hline High-voltage & 7.5 & 86.7 & 3.4 & 71.7 & 8.6 & 99.3 \\
\hline Distribution companies & 9.4 & 8.8 & & & 9.1 & 9.4 \\
\hline Traction & 7.9 & 18.9 & $11.2 \%$ & 8.2 & & \\
\hline $\begin{array}{l}\text { Electrochemical and electro- } \\
\text { metallurgy }\end{array}$ & 6.9 & 4.7 & $1.5^{*}$ & 55.4 & & \\
\hline Industrial & 7.1 & 54.3 & & & 8.3 & 89.9 \\
\hline Cement and paper industries & 8.2 & & 8.5 & 8.1 & 7.3 & 20.1 \\
\hline Altos Hornos de Vizcaya & 5.2 & & & & & \\
\hline Total & 10.5 & 100.0 & 9.2 & 100.0 & 8.6 & 100.0 \\
\hline
\end{tabular}

Note: *Own consumption.

Source: as Table 2.

This was because its structure of consumption was perfectly defined, basically industrial consumption, while in the other two companies it was more complex and dynamic; lighting and industry in Pamplona, plus its own consumption in the case of Irati. The second difference is seen in the fact that Fensa's prices were lower due to the nature of its production, capacity to store energy and the competitiveness of its market.

The competitiveness of the Navarra company is obvious if its prices are compared with those of the other companies from Guipúzcoa and Vizcaya (Table 5). After 1934, Fensa's average prices were lower than those 
TABLE 5

AVERAGE PRICE OF ELECTRICITY FOR FENSA'S MOST IMPORTANT CLIENTS, AND FOR OTHER COMPANIES OPERATING IN THE VASCO-NAVARRO MARKET (1930-1946)

(cents/kWh)

\begin{tabular}{|c|c|c|c|c|c|c|c|c|c|c|c|c|c|c|c|c|c|c|c|c|c|c|c|}
\hline \multirow[b]{3}{*}{ Year } & & & \multicolumn{13}{|c|}{ Prices offered by Fensa to: } & \multirow[b]{3}{*}{ Fensa $^{\mathrm{p}}$} & & & & & & & \\
\hline & \multicolumn{2}{|c|}{$\begin{array}{c}\text { Cement } \\
\text { companies }\end{array}$} & \multicolumn{6}{|c|}{ Paper manufacturers } & \multicolumn{7}{|c|}{ Distributors } & & \multicolumn{7}{|c|}{ Average prices of other companies } \\
\hline & $\mathbf{C P}^{\mathbf{a}}$ & $\mathbf{C R}^{\mathbf{b}}$ & $J^{\mathbf{c}}$ & $\mathbf{P A}^{\mathbf{d}}$ & $\mathbf{J C}^{\mathbf{e}}$ & RAC $^{\mathbf{f}}$ & $\mathbf{E G C}^{\mathrm{g}}$ & $\mathbf{P P} \mathbf{P}^{\mathbf{h}}$ & Ebch $^{\mathbf{i}}$ & $\mathbf{E C}^{\mathbf{j}}$ & CESS $^{\mathbf{k}}$ & $\mathbf{E R}^{\mathbf{l}}$ & $\mathbf{E b i}^{\mathbf{m}}$ & Eber $^{\mathbf{n}}$ & Arit $^{\circ}$ & & Arteta & Irati & Ibérica & Duero & Guip $^{\mathbf{q}}$ & Irurak & Bilbao \\
\hline 1930 & & & & & & & & & & & & & & & & 7,4 & 12.5 & 8.5 & 6.9 & & & & \\
\hline 1931 & 8.8 & & 8.1 & & & & & & & 5.9 & & & & 13.0 & & 7.3 & 11.3 & 9.2 & 6.9 & & & & \\
\hline 1932 & 7.8 & & 8.2 & & 8.2 & & 13.0 & & 10.4 & 4.0 & 12.0 & 10.0 & 10.0 & 12.8 & & 7.9 & 9.9 & 7.8 & 6.7 & & & & \\
\hline 1933 & 7.8 & 2.5 & 8.2 & & 8.3 & 8.2 & 13.3 & & 9.6 & 6.1 & 12.0 & 10.0 & 12.6 & 12.3 & & 7.8 & 11.4 & 9.3 & 6.7 & & & & \\
\hline 1934 & 7.7 & 2.8 & 8.2 & & 8.3 & 8.2 & 10.3 & & 10.2 & 6.4 & 11.9 & \begin{tabular}{|l|l|} 
\\
\end{tabular} & 10.1 & 12.8 & & 7.8 & 12.7 & 9.3 & 9.3 & & & & \\
\hline 1935 & 8.6 & 3.0 & \begin{tabular}{|l}
8.2 \\
\end{tabular} & & 8.2 & 8.2 & 11.0 & & 8.5 & 7.3 & & \begin{tabular}{|l|l|} 
\\
\end{tabular} & 11.8 & 12.6 & & 7.3 & 12.3 & 8.4 & 8.8 & 5.0 & 9.1 & 19.1 & 29.5 \\
\hline 1936 & 8.0 & 3.0 & 8.2 & 6.9 & 8.2 & 8.4 & 10.7 & & 9.9 & 6.8 & 9.7 & 10.4 & 13.0 & 13.0 & & 8.0 & 11.5 & 6.3 & 9.1 & 7.9 & 9.5 & 21.8 & 28.8 \\
\hline 1937 & 6.2 & 4.0 & 8.2 & 6.7 & 8.2 & 12.6 & 12.4 & 12.0 & 8.5 & 8.9 & 11.3 & \begin{tabular}{|l|l|}
10.4 \\
\end{tabular} & 16.1 & 12.6 & & 7.6 & 11.4 & 6.3 & 10.8 & 2.8 & 9.6 & 21.8 & 27.5 \\
\hline 1938 & 9.0 & 5.1 & 8.2 & 6.8 & 11.9 & 12.4 & 12.3 & 12.0 & 10.0 & 8.0 & 7.9 & 10.4 & 10.7 & 11.5 & & 7.5 & 11.5 & 6.8 & 9.7 & 5.0 & 9.8 & 19.8 & 27.6 \\
\hline 1939 & & 5.5 & \begin{tabular}{|l|}
8.2 \\
\end{tabular} & 6.7 & 12.4 & 12.4 & 12.4 & 12.0 & 8.5 & 7.6 & 6.2 & 10.4 & 12.2 & 10.8 & 8.0 & 7.8 & 11.3 & 7.9 & 8.7 & 5.0 & 9.8 & 20.2 & 29.6 \\
\hline 1940 & & 5.3 & 8.2 & 7.0 & 12.3 & 12.4 & 12.4 & & & & & & & & & 7.4 & & 8.9 & 8.3 & 8.0 & & 27.8 & \\
\hline 1941 & & & & & & & & & 10.2 & 9.9 & & & 10.7 & 10.0 & 9.1 & 8.7 & & 9.3 & 8.6 & 6.9 & & 26.0 & \\
\hline 1942 & & & & & & & & & 10.2 & 9.9 & & & 10.7 & 10.0 & 9.1 & 8.7 & & 10.0 & 9.6 & 7.4 & & 23.2 & \\
\hline
\end{tabular}


TABLE 5 (Cont.)

\begin{tabular}{|c|c|c|c|c|c|c|c|c|c|c|c|c|c|c|c|c|c|c|c|c|c|c|c|}
\hline \multirow[b]{3}{*}{ Year } & & & \multicolumn{13}{|c|}{ Prices offered by Fensa to: } & \multirow{2}{*}{\multicolumn{8}{|c|}{ Average prices of other companies }} \\
\hline & \multicolumn{2}{|c|}{$\begin{array}{c}\text { Cement } \\
\text { companies }\end{array}$} & \multicolumn{6}{|c|}{ Paper manufacturers } & \multicolumn{7}{|c|}{ Distributors } & & & & & & & & \\
\hline & $\mathbf{C P}^{\mathbf{a}}$ & $\mathbf{C R}^{\mathbf{b}}$ & $\mathbf{J E}^{\mathbf{c}}$ & $\mathbf{P A}^{\mathbf{d}}$ & $\mathbf{J C}^{\mathbf{e}}$ & $\mathbf{R A C}^{\mathbf{f}}$ & EGC $^{\mathbf{g}}$ & $\mathbf{P P}^{\mathbf{h}}$ & Ebch $^{\mathbf{i}}$ & $E \mathbf{C}^{\mathbf{j}}$ & CESS $^{k}$ & $\mathbf{E R}^{\mathbf{1}}$ & $\mathbf{E b i}^{\mathbf{m}}$ & Eber $^{\mathbf{n}}$ & Arit $^{\mathbf{o}}$ & Fensa $^{\mathrm{p}}$ & Arteta & Irati & Ibérica & Duero & Guip $^{\mathbf{q}}$ & Irurak & Bilbao \\
\hline 1943 & & 5.0 & 8.2 & 6.7 & & & 11.1 & 12.0 & & 8.0 & & 10.0 & 12.0 & 11.0 & 8.0 & 7.8 & & 11.0 & 9.1 & 8.0 & & 24.6 & \\
\hline 1944 & & 5.0 & 8.0 & 7.0 & & & 11.0 & & & & & & & & & 7.6 & & 11.3 & 11.5 & 6.9 & & & \\
\hline 1945 & & & & & & & & & & 8.0 & & 10.0 & & 11.0 & 8.0 & 7.0 & & 11.9 & 11.0 & 7.4 & & & \\
\hline 1946 & & 5.0 & 8.0 & 7.0 & & & 11.0 & & 9.6 & 6.7 & 9.5 & 11.3 & 11.7 & 11.9 & 8.0 & 6.8 & & 11.8 & 12.3 & 6.1 & & & \\
\hline
\end{tabular}

Source: For Fensa prices, see Table 2; for the other companies see Sources in the bibliography and the Annual Reports of each company cited.

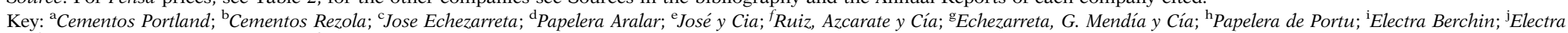

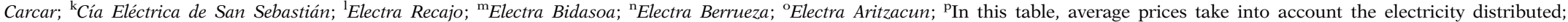
${ }^{\mathrm{q}}$ Distribuidora Eléctrica Guipúzcoana. In the rest of the tables of Fensa prices, however, the electricity taken into account is that which was consumed. 
of Ibérica and those of its most important subsidiaries ${ }^{23}$. In this advantageous situation for distribution, Fensa was able to cover its limited production capacity by seeking alliances with other producers (such as Saltos del Duero) and endangering the future influence of Ibérica in this unorganised market. On the other hand, the fact that the average prices of the Ibérica distributors in Guipúzcoa compared favourably with those of its distributors in Vizcaya was due to the monopoly exercised by Ibérica in the Vizcaya market, the type of clients reserved for the distributor in this market, generally low-voltage customers, and the lower level of energy produced by the company itself. The fact that Fensa's prices, except during the Civil War, appeared not to be very different from even those of a young, important production company like Saltos del Duero shows, once more, its competitiveness through prices and corroborates that the takeover of Fensa was closely related, in the first place, to its limited production resources and, as a consequence of this, its limited capacity to respond to the post-war restructuring of the Spanish electricity market.

While being aware of the fact that the average selling price of electricity can provide some indirect knowledge of its evolution, the most appropriate analysis to determine pricing policy in comparative terms requires a disaggregated study as made possible either by categories of consumption (lighting, power, traction) or types (high- and low-voltage supplies) ${ }^{24}$. Fensa offered more competitive prices than Ibérica especially in high-voltage supplies to paper and cement companies (the most important segment of its consumption) and to a lesser extent to distribution companies. The price advantage over low-voltage industrial supplies was not very relevant in terms of consumption for Fensa (Table 4).

\section{FENSA'S CONTRIBUTION TO THE FORMATION OF THE VASCO-NAVARRO ELECTRICITY MARKET}

The formation of Fensa's market is of interest in two senses. First, the fact that it was established relatively late at a time when the development of the Spanish electricity sector was quite advanced. Second, due to the strategic value it acquired for two large Spanish companies (Hidroeléctrica Ibérica and Saltos del Duero $^{25}$ ) in the control of the Vasco-Navarra market.

${ }^{23}$ Before this date, the prices offered by Fensa were higher than those of Ibérica for one main reason: its expansion in Guipúzcoa, intended to supplement the energy supply of a small group of industrial customers, was not allowed to conflict with the plans drawn up by Ibérica in this province. This situation of mutual respect had to change precisely when Fensa reached an agreement with Compañia Eléctrica de San Sebastián (1933) and Electra Berchín (owner of the Compañia de Tranvias de San Sebastián), two companies that provided light and low-voltage power to the heart of the province, its capital.

24 Another alternative would be to compare the individual company rates.

25 To properly understand the business context it is helpful to read Díaz Morlán (2006). 


\subsection{The first steps}

Although the demand for electricity in Guipúzcoa during this period increased, we can assume that the existing companies were not very happy about the entry of a new operator into the market. The possibility that Ibérica, the main producer in the region, would stop the Fensa project was unlikely. Among other reasons, this was due to the exploitation of the Alloz. reservoir, which was included in the new water policy of the State, with the support of the Hydrographic Confederations whose intentions were to re-launch the country's economic growth by fostering the development of multi-use dams related to agricultural irrigation and industrial electrification activities (see also footnote 21). The consumers must have had a different opinion. In principle, they would benefit from the price war that this new situation would generate, as well as from the extended and more specific supply.

The policy of Fensa up to the start of the Civil War was to give preference to the Guipúzcoa market, focussing on the capture of three areas of this market: (a) industries of a considerable size; (b) electricity companies; and (c) certain town councils. The Navarra company had a strategy that was similar to that displayed by the country's large electricity companies: to place its high-voltage production rapidly by way of contracts with large clients, thereby externalising the costs of distribution at low tension to the medium-sized local companies ${ }^{26}$.

\subsection{Relationships with the Guipúzcoan distributors and the first contacts with Ibérica}

Fensa multiplied its contacts with different Guipúzcoan electricity companies and, in June 1931, it began talks with Ibérica to try to avoid any competition that would be damaging to either party. It should be remembered that one of the preferred objectives of Ibérica, after the appearance of the largest electricity-generating company in the country (Saltos del Duero and the signing of the Pacto de Auxilio Mutuo with the Grupo HidroeléctricoHydro Group in $1930^{27}$ ), was to reinforce its production and financial position in the Guipúzcoa market. The approach by Fensa was brought to a successful conclusion by way of sporadic interchanges of electricity with Ibérica's most

${ }^{26}$ In the provincial market, Fensa signed its first contract for the sale of electricity with Cementos Portland in 1930, and it began negotiations with a number of local Navarra councils. This electricity was mainly used for public and domestic lighting and, to a lesser extent, for the supply of rural industries. The initial idea of setting up their own subsidiary distributor in Navarra for this purpose, as defended by the prestigious Spanish publicist and Fensa engineer Errandonea, was not put into practice. The company preferred to sell its electricity through small local distributors. This probably happened because the rationalization of distribution proposed by Errandonea, whilst profitable in the long term, required major investment in the short term and did not offer sufficient guarantees of profits in the medium term, given the geographical spread and level of consumption in this rural market.

27 Annual Reports of Hidroeléctrica Ibérica, 1930, pp. 7-8. 
important subsidiary in Guipúzcoa, the Distribuidora Eléctrica Guipúzcoana, and with one of the oldest companies in the capital, the Compañia Eléctrica de San Sebastián. Later, in 1933, the desire to consolidate relations with Ibérica through a project of minimum rules of exchange failed when the latter did not accept the conditions imposed by Fensa. Two years later, encouraged by substantial changes in the Vasco-Navarro market due to the agreement signed by Duero and Hydro Group (1934), the latter two companies signed a contract (21/10/1935) pending the approval of Duero. Meanwhile, partial agreements were formalized for the adjudication of new supplies, but this was not without tension between the respective distributors when defining prices and markets.

After 6 months of deferments, Fensa denounced the contract with Ibérica ${ }^{28}$, given that Duero did not ratify it. The Navarra company left and did not comply with its obligatory annual minimum consumption ( $2 \mathrm{GWh})$ or the parts of the agreement regarding rates, zones and link-ups. However, 2 months later, talks resumed, perhaps with the intention of qualifying certain matters established in the 1934 Agreement between Duero and Ibérica, which could have been an obstacle to the agreed contractual terms. Fensa expressed the following desires to Ibérica: (a) complete liberty to build its second hydropower station; (b) that the prices offered by Ibérica's distributing companies should be the same or higher than those offered by Fensa; (c) freedom of consumption during peak hours and a minimum price for the obligatory quota.

\subsection{The interconnection with the Basque network: Fensa, from independent company to distributor for Iberduero}

Why didn't Duero endorse the agreement between Ibérica and Fensa? The reply to this question is of great interest in understanding part of the new structure of the market in the north of the Peninsula. The appearance of Duero (the largest Spanish producer with no specific market of its own) on the scene not only affected the large north-west and south-east Spanish utilities, who were obliged to defend the status quo with the 1934 Agreement, but also much smaller ones, like Fensa, which had found a niche in the gaps of the TES. Consequently, Ibérica put pressure on its distributors to increase their consumption and strengthened its relationship with Compañia Eléctrica del Urumea and Eléctrica de San Sebastián. However, in addition to these common effects suffered by medium-sized and small companies ${ }^{29}$, the case of Fensa presented an additional peculiarity. This singularity was the result of the strategic position Fensa occupied for certain companies (Duero and Ibérica) as an instrument of penetration or as an obstacle to conquering the dynamic market of Guipúzcoa.

28 Records of Hidroeléctrica Ibérica's Board of Directors (from now on RHIBD), 15/04/1936.

29 Disputes over other adjoining markets (Electra Recajo, Hidroeléctrica Moncayo, EIA and ERZ) were also common in these years. RHIBD, 31/01/1936, 15/04/1936, 12/07/1937, and 02/12/1940. 
Duero, despite having reached an agreement with Ibérica over the sharing out of a large part of the market in the north of $\operatorname{Spain}^{30}$, knew that the production situation of its partner was not ideal for effective control of this market ${ }^{31}$. For this reason, although Duero was not in a position to demand this, neither would it favour the development and consolidation of Ibérica in these markets, because it did not want to strengthen Ibérica's negotiating position. In this way, Duero's refusal to approve the agreement between Ibérica and Fensa acquires its real significance. The result was that Duero would halt the expansion of Ibérica in important markets, Guipúzcoa and, to a lesser extent, Navarra, and would open the possibility of them entering these markets.

Two years after the end of the Civil War, on February 26, 1941, as Ibérica tried to set up a sole distributor to avoid competition in Guipúzcoa, Fensa resumed contacts with Ibérica and its subsidiaries (Distribuidora Eléctrica Guipúzcoana and Compañía Eléctrica del Urumea). However, as Fensa would not yield to the desires of Ibérica, in relation to the exchange of shares, and the price and quantity of the supply, the attempt failed. In 1943 the two companies got together again, at the request of Ibérica, to bring order into the Guipúzcoa market. This is hardly surprising considering that, according to Ibérica's board of directors: «the competition between the companies was great, and the abuse of the customers reached unsuspected heights ${ }^{32}$; apart from the economic burden that the electrical restrictions were causing to their balance sheets. But given that almost all of the solutions depended on the blessing of Duero, Fensa had no alternative but to sign a contract with that company to «share and supply» $(16 / 2 / 1944)^{33}$. The model of this contract was consistent with the commercial policy designed by Duero in 1932. This consisted of placing enormous quantities of energy in its "own markets» for distribution, as occurred in Castilla (Amigo 1992), through distributors in which it had a shareholding, as opposed to the idea of setting up a subsidiary for this purpose. In addition, Duero became the largest shareholder in Fensa, holding one-sixth of the paid-up capital, and Fensa became just one more distribution subsidiary.

Having reached this point, it is necessary to ask two questions. The first concerns the reasons that would explain the interference by Duero in the areas shared with Ibérica. The second question concerns the reasons why Fensa

${ }^{30}$ Under this agreement, the latter company would control the distribution exclusively in the provinces of Vizcaya, Alava, Guipúzcoa, Navarra, Logroño and the north of the province of Burgos. The Spanish market was divided into exclusive markets for Duero, Ibérica and Española and markets shared with Duero (by Viesgo, Ibérica, Española, Alberche and Castilla). In the latter, Ibérica acquired a quota from Saltos and when it finished the increases in consumption were split between Saltos and Ibérica.

31 In fact, in August 1939 and 1941, the directors of Ibérica gave sweeping powers to its chairman and his manager to make whatever efforts were necessary to sign agreements with respect to the Guipúzcoa and La Rioja markets, respectively. RHIBD, 28/08/1939, 26/01/1940, 16/05/1941, 25/08/1941 and 19/09/1941.

32 Annual Reports of Hidroeléctrica Ibérica, 1942, p. 6.

33 RFGM, 23/03/1944, pp. 76-91. 
became a subsidiary of Duero. As has been indicated on another occasion when explaining the formation of the Vasco-Navarro market (Garrués 1994), the replies to both questions should be analysed in the light of the effects of the agreement in 1942 between Saltos and Ibérica (Convenio 1942), which, substituting the document signed in 1934, reflected the new balance of forces existing between the two companies. Among other reasons, the 1942 Agreement meant a greater liberalisation of the market, implying the entry or participation in the market of a new producer (Duero) in those areas of intensive electricity demand that had previously been under the influence of Ibérica, but which it had not actually controlled. In exchange, Ibérica would be able to expand its production capacity through new facilities in order to deal with increases in consumption and put an end to the supply restrictions. Duero managed to "sell directly, using our own means of production, to high-voltage clients of their markets, a quantity of electricity equivalent to half of the total increase» ${ }^{34}$. From this we can understand Ibérica's loss of power in the Guipúzcoa, Navarra and Rioja markets, and the reason why Duero acquired distribution subsidiaries in markets that up to that time had been the domain of Ibérica, and, in this particular case, the strategic importance of Fensa.

The complex relationships were made more transparent after the birth of the largest Spanish electricity company, Iberduero (30/9/1944), a result of the merger between Ibérica and Duero. From this moment onwards, the sharing out of the market between different subsidiaries and/or parent companies would not take any longer than strictly necessary. The directors of Fensa, in almost all the meetings held in Bilbao with the board of Duero, showed great concern over the effects on its future of the birth of Iberduero, and in particular, over the validity of the 1942 Agreement. The board of the new company, however, managed to transmit the necessary reassurance. The proof of this is seen in the fact that in November of that year their networks were interconnected in a permanent way.

There were two consequences of the creation of Iberduero that were particularly important for Fensa, as will be explained later. These were: (a) the loss of autonomy in management, although for purely financial motives it survived as a subsidiary until 1991. Also as a result of this first consequence, (b) its new operative and commercial policies, now exclusively as a distribution company, directed at the organisation of the electricity markets in the centre and south of Navarra, ceding its traditional markets in Guipúzcoa and the north-west of Navarra to the parent company.

\subsection{The agreement with Saltos del Duero (1944) and the first actions as a subsidiary}

The directors of Fensa justified the "Share and Supply» agreement (16/2/ 1944) with Duero to their shareholders as the only way to avoid the company's

34 Annual Reports of Saltos del Duero, 1942. 
supply problems. The agreement was signed with Duero because it was the only company that would be able to offer the necessary supply guarantees. In effect, Duero said it would respect the industrial business of the Navarra company and offered a minimum quota of auxiliary energy $(6 \mathrm{GWh})$ at a reasonable price, as long as they held "control of Fensa (...) to avoid future competition, always disastrous to the interests of the companies» ${ }^{35}$. Although this control did not imply the dissolution of the company, it came at a great price: Duero became its major shareholder.

As for the supply contract, Fensa had discretional power over the distribution of the maximum quota that Duero had the right to commercialise in Guipúzcoa, Navarra and Logroño with the exception of the major consumers (10 GWh p.a.) who were served directly by Duero. The duration of the contract was conditioned by the 1942 Agreement between Duero and Ibérica, in other words until January 1, 1958. To Fensa, to have energy with no obligation in relation to minimum consumption periods (low water levels or winter), nor time (peak hours), meant it could count on a supply of permanent electricity in greater quantities than thermal energy, and at a cheaper price than hydro. In addition, this contract had the advantage of favouring the sale of Fensa's own production as constant energy, with the consequent improvement in sale prices, and guaranteed services of supply. The change in the composition of the shareholders would matter little or not at all to the directors and shareholders of Fensa. This was because they would be guaranteed the continued value, as opposed to the risks of a renewed market, where competition through production and prices could lead them to a progressive decapitalisation $^{36}$.

With the appearance on the scene of the new company, Iberduero occupied itself with the reorganisation of the Guipúzcoa market, leaving Fensa in charge of restructuring its southern market. With this intention, in September 1946 Fensa acquired Electra Pamplona, an old Ibérica subsidiary, in exchange for its distributive and productive elements (Saltos de Ituren and Electra Aritzacun) in Guipúzcoa. With this exchange of assets, Iberduero went from controlling one-sixth of Fensa's capital to having more than 50 per cent of its shares. It was then that Iberduero changed the articles of incorporation of Fensa, reducing the power of its board of directors and modifying its traditional way of sharing profits.

35 RFBD, 4/03/1944, p. 104.

36 The agreement between Saltos and Fensa allowed the latter company to maintain its traditional structure of dividends: 5 per cent to capital reserves; 10 per cent to the board of directors; up to a maximun 7 per cent of capital invested by shareholders; and the rest as decided by the General Meeting of Shareholders. It should be noted, however, that the downward trend of Fensa's dividends between the end of the Civil War and 1944 (4 per cent in the last year) contrasted with the positive evolution of other companies like Saltos (6.30 per cent in 1944) or Ibérica (6 per cent in the same year; Appendix 2). 
FIGURE 3

EVOLUTION OF FENSA'S RETURN ON ASSETS (ROA), RETURN ON EQUITY (ROE) AND DEBT 1930-1980 (\%)

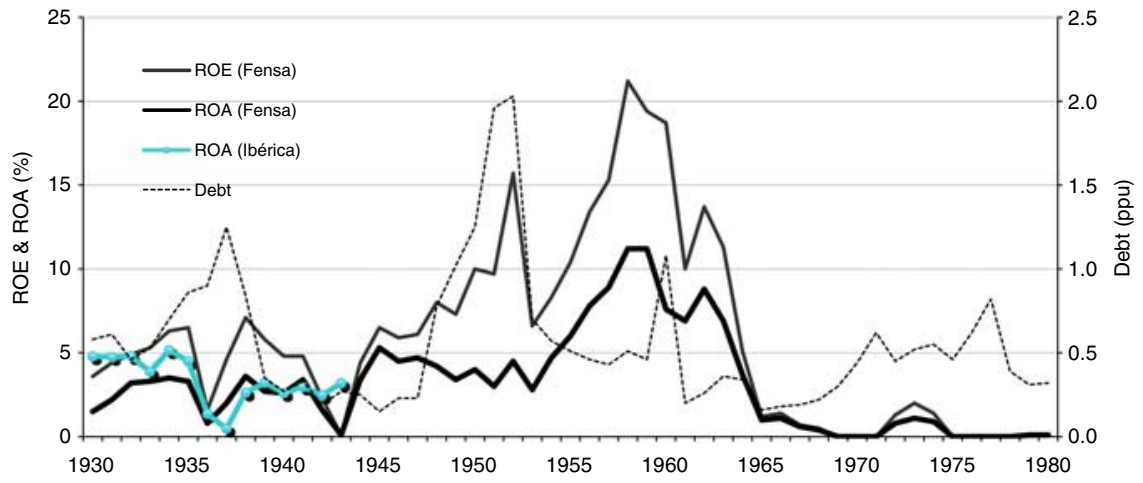

Source: see Appendices 1 and 2

\section{ECONOMIC PROFITABILITY}

It can be stated that the return on Fensa's assets (ROA) improved when the company became integrated into the Iberduero system (Figure 3$)^{37}$. The variations in factors of an industrial nature (initially due to financial costs ${ }^{38}$ and, later, due to those arising from productive insufficiencies ${ }^{39}$ ), compared with a relatively stable commercial factor (sale prices) and a less than efficient management of assets (among other reasons, due to the delays suffered

37 For a more detailed analysis, see Garrués (1996, pp. 740-749).

38 Financial expenses were increased from 1934 to 1940 . Up to 1934 the company's finance had been based largely on self-financing (based on increasing the capital share in 1928). Thereafter, the expenses incurred by the electricity infrastructure, the recovery of Hidroeléctrica de Alloz. foundation obligations and bond investments in subsidiaries to restructure (Ituren and Aritzacun) demanded that Fensa also use long-term and short-term external financing (through 5,000 mortgage bonds in 1934 and 2,000 in 1937). This meant a significant increase in annual interest rate and depreciation. The situation was corrected, however, by taking advantage of the fact that new funds were needed to build the second waterfall and to alleviate the debts incurred they resorted to self-financing again (a capital share increase of 6 million pesetas in 1939, 8 million in 1940 and 10 million in 1942).

39 The downturn in the ROS (rate on sales) was due, on the one hand, to a combination of relatively low electricity prices and rising costs. Within the latter were the especially burdensome costs of purchasing power from third parties. This issue was closely linked to the evolution of demand and the gradual strangulation of its own production, rather than the possible variation in the prices of purchased energy. In no case did it exceed 7 cents/kWh. The purchase of electricity between 1938 and 1944 was increased by 6 per cent, constituting by the latter date, 60 per cent of the total expenditure. 
in investments becoming productive $\mathrm{e}^{40}$ ), explain the limited and unequal development in profitability in the first phase (1930-1944).

In the second half of the 1940s and the early-1950s (1945-1953), by then as a subsidiary of Iberduero, profitability did not improve substantially because the restructuring of the Navarra market (the takeovers of $E P, H M, H C V, E v z, E T$ and $E E$ ) had a high cost for the company ${ }^{41}$. The greater development of ROA in the third stage (1954-1959) was due, in part, to the fact that Fensa managed to improve its profits per unit (TTUs and financial reorganisation ${ }^{42}$ ), and also because it achieved a more adequate management of its assets. This positive evolution should have been maintained in the last period (1960-1980), but the takeover of Irati-Arteta ${ }^{43}$ (1961) and, above all, the new policy of Iberduero in relation to the self-financing of Fensa, which reduced declared profits to a minimum, did not help to specify the development of this variable adequately ${ }^{44}$.

The development of Fensa was financed with its own capital, which gave it acceptable levels of solvency and indebtedness (Figure 3). Fensa's financing was not as advantageous as that of certain large companies like Ibérica or Hidrola, which, having the financial support of large banks from the beginning, could make financing more intense, agile and less costly in terms of the use of credit, and even in the handling of bonds ${ }^{45}$. Unlike large companies, the difficulties in obtaining finance capital made Fensa prefer very conservative financial policies based on equity capital (capital increases). Meanwhile, Ibérica made a relatively greater use of credit, while Hidrola opted for the use of bonds ${ }^{46}$. The consequence of Fensa's conservative policy was a reduced capacity for risk-taking and new investment and, ultimately, a greater dependence on and vulnerability to the growing competitiveness of the large companies.

40 The results of 1943, for example, demoralized the Fensa board of directors, especially when they saw that more than 50 per cent of capital invested in the construction of the second power station had not begun to offer results.

41 This explains the difference between the ROA and return on equity (ROE). Between 1947 and 1952, the long-term liabilities increased from 1.7 to 52.7 million pesetas while the capital share of the company was only 30 million.

42 Among others, it was important to increase the capital share in 1953.

43 The takeover of Irati-Arteta required a capital share of 100 million pesetas. This increased from 60 to 160 million pesetas.

${ }^{44}$ This company, once it had completed its main task, the concentration of Navarra market and, above all, when Iberduero became its sole shareholder (1966), suffered a significant mutation. That is why Iberduero showed no interest in distributing profits according to the real business, especially when they had to pay significant taxes. Iberduero, taking advantage of regional and state legislation, consequently reduced its profits by increasing depreciation and reserves.

${ }^{45}$ Regarding the relationship between Ibérica and Banco Vizcaya, see Antolín (1996), pp. 251-252 and on the interconnection between Hidrola and diverse financial groups (Banco de Vizcaya, Banco Central y Banco Hispano Americano) and its impact in the business and financial strategy, see Aubanell (2000, pp. 155-162) and Tedde and Aubanell (2006, pp. 170-177).

46 However, the relationship between equity capital and obligations in Ibérica and Española was very similar (1921-1929, 0.9 and 1930-1936, 1.7; 1938-1944, 3.0) (Antolín 2006; Tedde and Aubanell 2006). As expected this ratio was in favour of the equity capital (1916-30, 2.1 and 1937-1944, 5.3) in Fensa's case (Garrués 1996). 
Beyond this consideration, the analysis of the financial evolution needs certain clarifications.

As an independent company, growing financial demands forced it to resort to external capital. Although this did not endanger the company's solvency, it led it to worrying levels of indebtedness, especially between 1934 and 1938. This situation was corrected through three capital increases (1939, 1940 and 1942), which allowed it to reduce the imbalance in its financial structure and indebtedness, and also allowed it to commit to important investments in such a way that, although profitability in the first half of the 1940s was very weak, the same thing did not happen with its financial situation. Consequently, if the conversion of Fensa into a subsidiary of Saltos del Duero was unavoidable, above all taking into account the medium-term economic situation, this was not the case from a financial point of view. This being so, the interest of Saltos del Duero in acquiring the services of this company, apart from those mentioned in the reform of the Guipúzcoa-Navarra market, would only increase.

In the first years (1948-1958) as a subsidiary of Iberduero, Fensa's financial structure, solvency and indebtedness showed negative trends. This situation can be understood if one takes into account the cost that it had to pay, as a subsidiary, for the restructuring of its new market. From that time onwards, the financial situation of the company progressed without any major problems, as far as Iberduero allowed it a sufficient margin of operation to achieve a sufficient level of self-finance.

The comparison of the economic-financial situations of Fensa and Ibérica shows that, although from 1938 the profitability of the Navarra company was not very different from that of the company from Vizcaya and their commercial and industrial margins were comparable, their capacity for manoeuvre was radically different. Ibérica was in a phase of rapid expansion while Fensa was struggling to survive in the market. In addition, the financial behaviour of Ibérica indicates a stability that is not comparable in any way to that of Fensa because the slightest setback destabilised its accounts. It is hardly necessary to observe that, in contrast, the shareholding in Ibérica maintained by some of the most important financial institutions in the country gave the company a guarantee that the medium-sized electricity companies could not compete with. However, the evolution of costs speaks volumes. The crisis in the TES occurred when the unit costs of the small or medium companies (e.g. Arteta, Fensa and Irati) were higher than those of the larger companies (e.g. Ibérica; Figure 4).

\section{EPILOGUE: INTEGRATION OF THE NAVARRA MARKET INTO IBERDUERO'S SYSTEM}

The transformation of Fensa into a subsidiary of Iberduero meant a radical change in its development. On the supply side, within a few years it 
FIGURE 4

EVOLUTION OF REAL UNIT COSTS OF FENSA, IBÉRICA, IRATI AND ARTETA (1900-1965). POLINOMIC TENDENCY (Cents-1913-/kWh)

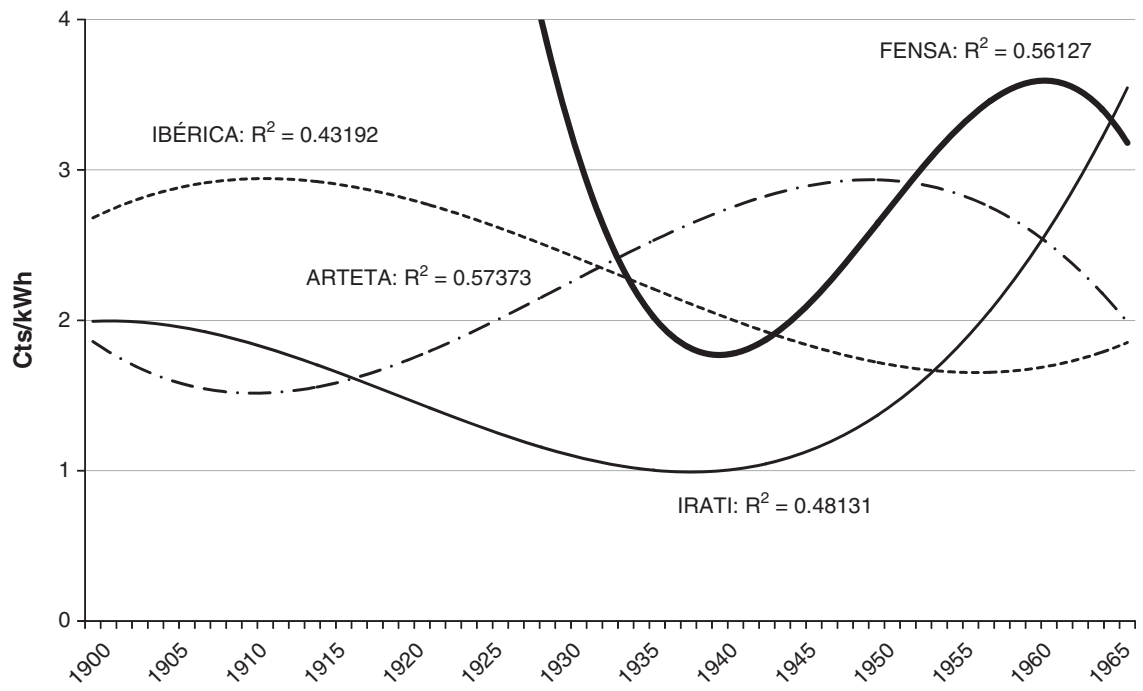

Source: see Appendix 1.

became the most important distributor in Navarra. In 1954, the electricity bought from Iberduero amounted to more than half of the energy distributed by Fensa, by 1980 it amounted to almost 100 per cent (Figure 5). The acquisitions of energy before the 1970s were marked by a strong increase in demand on the TES, which could not be satisfied by the as yet unconsolidated integrated systems. From that time onwards, the growth in energy bought by Fensa evolved at a rate imposed by the needs of the consumer market. The development in its own production, after its Mañeru hydropower station came on line (1944), was due to the incorporation of production and distribution assets that Fensa was absorbing ${ }^{47}$ and to the greater rationalisation of generation, the automation of hydropower stations, of transport and of the commercialisation of the electricity supplied to the network.

As part of this idea of optimisation, Fensa improved the lines of transmission that supplied the important nuclei of consumption, adjusting them to the same voltage as Iberduero's system. It managed to eliminate two of the

47 Among others: Electra de Pamplona, 1946; Hidráulica Moncayo, 1948; Hidroeléctrica Cinco Villas, Electra Vozmediano and Electra Turiano, 1949; Central de Añón, 1950; Electra Estellesa, 1951; Alfaro Hnos. y Vda. de Gambarte and Sdad. de Maderas, 1962; Hidráulica Urederra, 1965, etc. 
FIGURE 5

EVOLUTION OF ELECTRICITY DISTRIBUTED AND CONSUMED IN FENSA'S MARKET (1947-1980)

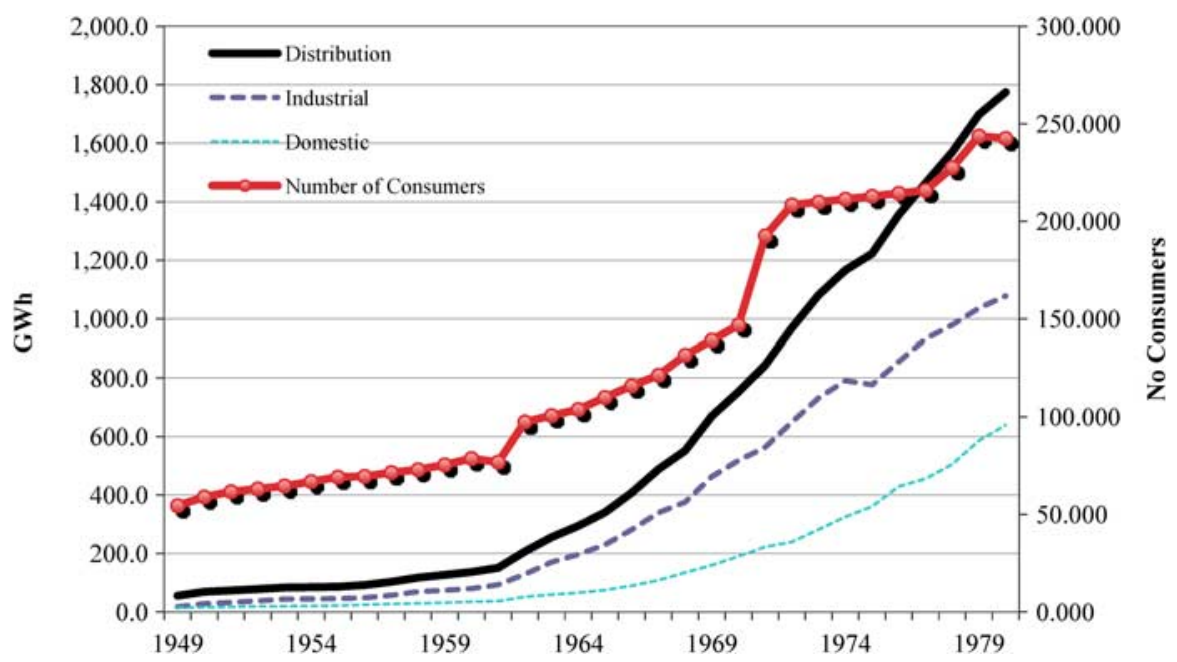

Source: Appendix 1.

evils that had long affected almost all of the TES, that is to say losses in distribution and consumer fraud.

The process of modernisation also affected Fensa's own means of production. From the mid-1960s, hydropower stations were automated, new groups and sub-stations were installed and the capacity of others was increased. In the 1980s, Fensa undertook the recovery of the micropower stations paving the way for the agreement signed between the Administration and Unesa in 1981. In Navarra the task of recovering the micro-power stations fell to a new company, Energía Hidroeléctrica de Navarra (EHN).

The evolution of energy consumption in Fensa's market closely followed the same tendency noted in the evolution of energy distributed. With the passage of time, and the extent to which transmission and distribution losses were notably reduced, they converged ${ }^{48}$. The level of consumption grew continually from the 1950 s to the time of the first oil crisis (14 per cent), when it suffered a strong setback, above all in industrial consumption (Appendix 1).

48 The loss went from 30 per cent of energy distributed in the late-1940s, to just 5 per cent in the early-1980s. 
The rapid increase of the 1950s and 1960s was not produced merely by the rate of industrialisation and urban development in the province, but also by the dramatic expansion of Fensa through the absorption of other companies. With respect to the territorial extension, in 1965, for example, the electricity used by its clients amounted to $\sim 72$ per cent of the total consumed in Navarra. As for the intensity of consumption, that the majority of the electricity was distributed at low voltage confirms the company's known role as a distributor. In any case, the evolution of consumption proves the fact that industrial and urban development in the 1950s and 1960s underwent a strong boom, echoing its course of the first third of the century. The growing importance of industrial consumption, compared with domestic and agricultural consumption, gives an idea of the industrial dynamism of those years. Whilst in 1950 industrial use amounted to 50 per cent of total consumption, 13 years later it came to 71 per cent.

There is no doubt, in this sense, that had Navarra continued to be restricted exclusively to TES, it would have been left behind in the first great wave of industrialisation in post-war Spain, and its inhabitants' standard of living would have been adversely affected. That this is so does not mean that the TES did not play a hugely important economic role, although not all reached the level of efficiency of some regional integrated systems.

\section{CONCLUSIONS}

In the Spanish electricity sector, as in the majority of other European electricity sectors until their nationalisation after the Second World War, large companies co-existed alongside what are called TES. With the spread of high-voltage transmission, the TES gradually disappeared as the large companies benefited from huge economies of scale and network, typical of the first IES. The establishment and market domination of the large companies was a process that in some countries, like Spain, was relatively slow. Thus, the benefits of this new industrial organisation came once the main technological and construction restrictions had been overcome after the First World War. The importance of the TES, however, should not be restricted exclusively to the peripheral areas or those that were economically less developed. In Spain, deficient government regulation (Pueyo 2006, pp. 63-111; Cayón 2009) and collusive agreements between firms allowed the large companies to renounce their natural territorial expansion because they preferred to externalise the high costs of distribution-commercialisation to TES companies.

Within the small- and medium-sized electricity companies, the case study of Fensa provides a good number of suggestive contributions to consider from three different viewpoints: (a) the business strategy, observed through the decisions taken by its directors; (b) the industrial organisation, seen through its behaviour in a situation of transition to the establishment of the 
first oligopolistic integrated system, previous to the current structure of the market; and (c) the level of regional development.

(a) The birth of Fensa shows how in provinces with limited industrial development (e.g. Navarra), it is possible to recognise outstanding business initiatives. This was because it was capable of constructing a lucrative and relatively novel business starting from an idea that had previously failed (Hidroeléctrica de Alloz). In fact, by way of applying the latest technology available on the construction of dams (dome type), it was able to make use of the hitherto unused water resources available (the River Salado). In contrast to the Spanish electricity companies of the time (which managed to enter the business due to the unrivalled strength provided by a solid financial support base and enormous quantities of energy, e.g. Ibérica, Hidrola or Saltos), Fensa entered the business with the backing of the regional middle class and with differentiation of its product: the kilowatts that it sold during periods of low water levels.

(b) From the industrial organisation viewpoint, Fensa had the advantage of operating in a very dynamic industrial market (Guipúzcoa), which was still barely controlled by Ibérica: the large Basque company that was capable of imposing, when its production surpluses permitted, its monopolistic power. This situation occurred with the opening of the second exploitation that Ibérica constructed in the Pyrenees (42,000 kW) in 1932 (Antolín 1989, 2006; Garrués 1994). However, the dramatic effect of the appearance of the largest Spanish producer without its own market (Saltos del Duero), due to its exploitation of the Ricobayo waterfall $(88,000 \mathrm{~kW})$, changed the Spanish electricity panorama. In fact, the efforts of Fensa to reach an agreement with Ibérica that would allow it to increase its production and avoid damaging competition (the 1935 contract) were unsuccessful. This was because Fensa, like many other companies from the TES, became a pawn in the game of alliances designed by the large companies. The agreements signed between the Hydro Group and Saltos (1934 and 1942/1943) to share out the Spanish market, with the exception of Catalonia, Galicia and Andalusia, were a good example. In the hidden confrontation between Duero and Ibérica to acquire the largest share of so-called "shared markets», Fensa became a key element for control of these markets. This was because it was the only strategically important and independent company in the Guipúzcoa and Navarra markets. For this reason Duero did not accept Ibérica's contract with Fensa, and the latter company, captive to its productive limitations during the period of restrictions, became its subsidiary.

In reality, by this stage in the development of the Spanish electricity system, the survival of the TES had become more and more difficult. The market power exercised by the large companies (based on their productive and financial superiority) was way beyond any possible strengths of any of the traditional companies that, like Fensa, had stood out for their productive specialisation, competitive pricing policy and reasonable profitability. With the appearance of Iberduero (from the merger between Duero and 
Ibérica), Fensa's role, as its distribution company, was to organise and modernise the Navarra market. This task lasted until well into the 1980s.

(c) As far as regional development is concerned, Fensa contributed in a decisive way. First, it alleviated the electricity shortages and intensified electrification in one of the most industrially dynamic provinces of Spain (Guipúzcoa) during the 1930s and 1940s. Second, Fensa contributed as a distributor for the largest hydroelectric company in the country by integrating the old TES in Navarra into Iberduero's electricity system. This meant that the electricity supply problems would not be a hindrance to the important economic takeoff of Navarra's industry in the second half of the $20^{\text {th }}$ century.

Despite what has been said, and in contrast to other countries ${ }^{49}$, in Spain the development of the medium-sized and small companies remained an unresolved problem. This is the case because without government regulation, which would defend their status, they were left defenceless against the expansionist logic of the large companies. In fact, at the beginning of the 1980s when they could have benefited from the new structuring of the electricity business (Garrués 2010) (according to free market principles and the setting up of the state transmission company, REE; Garrués and López 2009), it was already too late. Most of the companies had disappeared, or in the best of cases were no more than oddities of industrial archaeology. For this reason TES have not received the attention they merit in economic history. Without doubt, this case study and comparative analysis will help to display the complexity of the subject and will provoke future debate.

\section{SOURCES}

Archives of Iberdrola. Ricobayo.

- Annual Reports of Arteta (1930-1941).

- Anuario Financiero y de Sociedades Anónimas de España (several years).

- Annual Reports of Conducción de Aguas Arteta (1893-1936).

- Annual Reports of Distribuidora Eléctrica Guipúzcoana (1924-1936).

- Annual Reports of El Irati (1908-1960).

- Annual Reports of Fensa (1930-1990).

- Annual Reports of Hidroeléctrica Ibérica/ Iberduero (1904-1968).

- Annual Reports of Irati (1930-1959).

- Annual Reports of Saltos del Duero (1935-1946).

- General Ledger of Fensa (1927-1946).

- Records of Fensa Board of Directors (RFBD) (1930-1990).

${ }^{49}$ For example, the United States, with its statute conceded to small municipal electricity companies in the 1930s (R.E.A.) or the Qualifying Facilities (QFs) embodied in the Public Utilities Regulatory Policies Act of 1978 (PURPA). 
- Records of Fensa General Shareholders' Meeting (RFGM) (1930-1990).

- Records of Hidroeléctrica Ibérica Board of Directors (RHIBD) (1904-1944).

- Technical Record of the Five Year Period (1940). (1935-1939).

\section{REFERENCES}

Amigo, P. (1989): "Orígenes y evolución de la especialización castellano-leonesa en la producción nacional de energía eléctrica». Anales de estudios económicos y empresariales 4, pp. 103-122.

Aмigo, P. (1992): «La formación del mercado eléctrico nacional en España: la aportación de Castilla y León». Cuadernos de Economía de Castilla y León 2, pp. 119-153.

ANTOLín, F. (1988): «Un servicio publico con escasa intervencion. Los primeros cuarenta años de electricidad en España». Economía Industrial 262, pp. 27-38.

Antolín, F. (1989): «Hidroeléctrica Ibérica y la electrificación del País Vasco». Economía Pública 4, pp. 107-130.

Antolín, F. (1996): «Hidroeléctrica Ibérica y la electrificación del País Vasco», in F. Comín, and P. Martín Aceña (eds), La empresa en la historia de España. Madrid: Civitas, pp. 237-264.

Antolín, F. (2006): «Hidroeléctrica Ibérica (1901-1944)», in G. Anes (coord.), Un siglo de luz: historia empresarial de Iberdrola. Madrid: Iberdrola, pp. 131-191.

Aubanell, A. M. (1992): «La competencia en la distribucion de electricidad en Madrid, 1890-1913». Revista de Historia Industrial 2, pp. 143-171.

Aubanell, A. M. (2000): «Estrategia empresarial y estrategia financiera de la Sociedad Hidroeléctrica Española, 1907-1935». Revista de Historia Industrial 17, pp. 153-185.

Aubanell, A. M. (2005): “¿Era la industria electrica de entreguerras un monopolio natural? Evidencia a partir de la Sociedad Hidroeléctrica Española». Revista de Historia Económica 23, pp. 489-514.

Bartolomé, I. (2005): «La red nacional y la integracion de los mercados eléctricos españoles durante los años de entreguerras: ¿otra oportunidad perdida?». Revista de Historia Económica 23, pp. 269-298.

Bartolomé, I. (2007): La industria eléctrica en España, 1890-1936. Madrid: Banco de España.

Bartolomé, I. (2011): “¿Fue el sector eléctrico un gran beneficiario de la 'política hidráulica' con anterioridad a la guerra civil?». Hispania 239, pp. 719-818.

Bernal, A. M. (1993): "Ingenieros-empresarios en el desarrollo del sector eléctrico español: Mengemor, 1904-1951». Revista de Historia Industrial 3, pp. 93-126.

Bernal, A. M. (1994): «Historia de la Compañía Sevillana de Electricidad (1894-1983)», in J. Alcaide (ed.), La Compañía Sevillana de Electricidad. Cien Años de Historia. Sevilla: Fundación Sevillana de Electricidad, pp. 160-271.

CAPEL, H., and Urteaga, L. (1994): «El triunfo de la hidroelectricidad y la expansión de La Canadiense», in H. Capel (dir.), Las Tres Chimeneas. Implantacion industrial, cambio tecnológico y transformacion de un espacio urbano barcelonés. Barcelona: Fuerzas Eléctricas de Cataluña S. A., pp. 13-81.

CARmona, X. (1999): «Galicia en el desarrollo del sector eléctrico español (1900-1982)», in A. Carreras (ed.), Doctor Jordi Nadal. La industrialización y el desarrollo económico de España. Barcelona: Universitat de Barcelona, pp. 1378-1397. 
Cayón, F. (1998): Un análisis del sector eléctrico en Madrid a través de las empresas Hidroeléctrica Española, Electra Madrid y Unión Eléctrica Madrileña (1907-1936). Madrid: Fundación Empresa Pública, 9708.

CAYón, F. (2002): «Hidroeléctrica Española: Un análisis de sus primeros años de actividad (1907-1936)». Revista de Historia Económica 20, pp. 301-334.

CAYón, F. (2009): La regulación del sector eléctrico en España antes de la Guerra Civil. Working Paper Series, Economic History, no. 6. Madrid: Universidad Autónoma de Madrid.

Chandere, A. D. (1990): Scale and Scope: The Dynamics of Industrial Capitalism. Cambridge: The Belknap Press of Harvard University Press.

Convenio (1942): entre Saltos del Duero e Hidroeléctrica Ibérica de 31 de diciembre que sustituye el Convenio de 1 de febrero de 1936. Archivo de Iberduero. Secretaría técnica de dirección. Centro de documentación, registrado el 22 de noviembre de 1978, n. ${ }^{\circ}$ 24102, firmado por el Director general de Saltos (Ricardo Rubio) y el Director gerente de Ibérica (Enrique Uriarte), pp 1-8.

Díaz Morlán, P. (1998): «El proceso de creación de Saltos del Duero (1917-1935)». Revista de Historia Industrial 13, pp. 181-200.

Díaz Morlán, P. (2006): «Saltos del Duero (1918-1944)», in G. Anes (coord.), Un siglo de luz: historia empresarial de Iberdrola. Madrid: Fundación Iberdrola, pp. 279-324.

DíAz Morlán, P., and SAN Román, E. (2009): "Causas de la restricción eléctrica en el primer franquismo: una aportación desde la historia empresarial». Investigaciones de Historia Económica 13, pp. 73-95.

Errandonea, E. (1931): "Aprovechamiento hidroeléctrico del río Salado en Alloz». Revista de Obras Públicas 79, pp. 2585-2586, pp. 453-461 and pp. 477-483.

GARRUÉs, J. (1994): "La formación del mercado eléctrico Vasconavarro e Hidoeléctrica Ibérica», in P. Martín Aceña, y M. Gárate (eds), Economía y empresa en el norte de España. San Sebastián: Universidad del País Vasco, pp. 185-214.

GARRUÉs, J. (1996): El proceso de industrialización en Navarra: el desarrollo del sector eléctrico, 1888-1980. [microfoma, 1999]. Granada: Universidad de Granada.

GARRUÉs, J. (1997): Empresas y empresarios en Navarra. La industria eléctrica, 1888-1986. Pamplona: Gobierno de Navarra.

GARRUÉs, J. (2006a): «Electricidad e industria en la España rural: el Irati, 1904-1961». Revista de Historia Económica - Journal of Iberian and Latin American Economic History 24, pp. 97-138.

GARRUÉs, J. (2006b): «Mérito y problema de las eléctricas pioneras: Arteta, 1893/98-1961». Revista de Historia Industrial 31, pp. 65-106.

GARRuÉs, J. (2010): "Market Power vs. Regulatory Power in the Spanish Electricity System, 1973-1996». Renewable \& Sustainable Energy Reviews 14, pp. 655-666.

GARRUÉs, J., and López, S. (2009): "Red Eléctrica de España S.A.: Instrument of Regulation and Liberalization of the Spanish Electricity Market (1944-2004)». Renewable \& Sustainable Energy Reviews 13, pp. 2061-2069.

Germán, L. (ed.) (1990) ERZ (1910-1990). El desarrollo del sector eléctrico en Aragón. Zaragoza: Instituto Fernando el Católico-ERZ.

Gomez Mendoza, A. (2006): «Hidroeléctrica Española en los años 1940-1973», in G. Anes (coord.), Un siglo de luz: historia empresarial de Iberdrola. Madrid: Fundación Iberdrola, pp. 421-460.

Hausman, W. J.; Neufeld, J. L., and WiLkins, M. (2008): "The Invention and Spread of Electric Utilities, with a Measure of the Extent of Foreign Ownership», in W. Hausman, P. Hertner, and M. Wilkins (eds), Global Electrification. Multinational Enterprise and International Finance in the History of Light and Power, 1878-2007. New York: Cambridge University Press, pp. 3-34. 
Hidalgo, A. (2012): «Colusión y competencia en el mercado eléctrico valenciano antes de la guerra civil». Revista de Historia Industrial 48, pp. 81-117.

Hirsh, R. F. (2001): Power Loss: The Origins of Deregulation and Restructuring in the American Electric Utility System. Cambridge: The MIT Press.

Joskow, P., and Schmanlensee, R. (1983): Markets of Power. An Analysis of Electricity Utility Deregulation. Cambridge: MIT.

Neufeld, J. L (1987): «Price Discrimination and the Adoption of the Electricity Demand Charge». The Journal of Economic History 47, pp. 693-709.

Maluduer de Motes, J. (1983): «L'electricitat», in J. Nadal, A. Carreras, J. Maluquer, and C. Sudrià (eds), Produccio i consum d'energia en el creixement económico modern: el caso català. Cap. 6 (typescript).

Maluquer de Motes, J. (1992): «Los pioneros de la segunda revolución industrial en España: La Sociedad Española de Electricidad (1881-1894)». Revista de Historia Industrial 2, pp. 121-142.

Maluquer De Motes, J. (2006): «Panorama eléctrico español hasta 1944», in G. Anes (coord.), Un siglo de luz: historia empresarial de Iberdrola. Madrid: Iberdrola, pp. 53-94.

Newbery, D. (1999): Privatization, Restructuring and Regulation of Network Utilities. Cambridge and London: The MIT Press.

North, C. D. (1990): Institutions, Institutional Change, and Economic Performance. Cambridge: Cambridge University Press.

NúÑEZ, G. (1994): «Origen e integración de la industria eléctrica en Andalucía y Badajoz», in J. Alcaide (ed.), La Compañia Sevillana de Electricidad. Cien Años de Historia. Sevilla: Fundación Sevillana de Electricidad, pp. 127-159.

NúÑEZ, G. (1995): «Empresas de producción y distribución de electricidad en España, 1878-1953». Revista de Historia Industrial 7, pp. 39-80.

NúñEz, G. (1997): «Notas sobre la industria eléctrica en la alta Andalucía». Boletín del Instituto de Estudios Giennenses 167, pp. 73-102.

Pueyo, J. (2006): «La regulación de la industria de producción y distribución de energía eléctrica en España, 1939-1972», in G. Anes (coord.), Un siglo de luz: historia empresarial de Iberdrola. Madrid: Fundación Iberdrola, pp. 61-439.

Sindicato de Aguas, Gas y Electricidad (1949): Datos estadísticos técnicos de las centrales eléctricas españolas. Madrid: Servicio Nacional de Estadística.

Sirvent, I.; Mounton, E., and DE la Fuente, M. (1960): "Consideraciones sobre el desarrollo de la red de transporte de energía eléctrica en España». Madrid: World Power Conference, Sectional Meeting, Spain, 5-9 June, pp. 1-15.

SuDRIÀ, C. (1987): «Les restrictions de la consommation d'électricité en Espagne pendant l'après-guerre, 1944-1954», in F. Cardot (ed.), 1880-1980: un siècle d'électricité dans le monde. Paris: Presses Universitaires de France.

SUDRIÀ, C. (2006): «Iberduero, 1944-1973: la consolidación de un gran proyecto empresarial», in G. Anes (coord.), Un siglo de luz: historia empresarial de Iberdrola. Madrid: Fundación Iberdrola, pp. 383-419.

Tedde, P., and Aubanell, A. M. (2006): «Hidroeléctrica Española (1907-1936)», in G. Anes (coord.), Un siglo de luz: historia empresarial de Iberdrola. Madrid: Iberdrola, pp. 193-277.

URRUTIA, V. (1926): «Aspecto económico de las explotaciones hidroeléctricas». Ingeniería y Construcción 48, pp. 248-252.

Valdaliso, J. M. (2006): «Los orígenes de Hidroeléctrica Ibérica, Hidroeléctrica Española y Saltos del Duero», in G. Anes (coord.), Un siglo de luz: historia empresarial de Iberdrola. Madrid: Iberdrola, pp. 97-130. 
APPENDIX 1

CLIENTS, PRODUCTION, CONSUMPTION, FINANCIAL RATIOS AND UNIT COSTS OF FENSA (1930-1980)

\begin{tabular}{|c|c|c|c|c|c|c|c|c|c|c|c|c|c|c|c|c|}
\hline \multirow{3}{*}{ Year } & \multirow[t]{3}{*}{ Clients } & \multicolumn{3}{|c|}{ Production } & \multicolumn{3}{|c|}{ Consumption } & \multicolumn{5}{|c|}{ Economic financial ratios } & \multicolumn{4}{|c|}{ Real unit cost } \\
\hline & & \multirow[b]{2}{*}{ Own } & \multirow[b]{2}{*}{ Acquired } & \multirow[b]{2}{*}{ Distributed } & \multirow[b]{2}{*}{ Total } & \multirow[b]{2}{*}{ Industrial } & \multirow[b]{2}{*}{ Domestic } & \multicolumn{3}{|c|}{ Fensa } & \multicolumn{2}{|c|}{ Ibérica } & \multirow[b]{2}{*}{ Arteta } & \multirow[b]{2}{*}{ Irati } & \multirow[b]{2}{*}{ Ibérica } & \multirow[b]{2}{*}{ Fensa } \\
\hline & & & & & & & & ROE & ROA & Debt & ROE & ROA & & & & \\
\hline & $\begin{array}{l}\text { No. from } 1949 \\
\text { (thousands) }\end{array}$ & \multicolumn{3}{|c|}{ GWh } & GWh & \multicolumn{2}{|c|}{$\%$} & \multicolumn{2}{|c|}{$\%$} & ppu & \multicolumn{2}{|c|}{$\%$} & \multicolumn{4}{|c|}{$\begin{array}{c}\text { Cents/kWh @ } 1913 \text { value } \\
3 \text { year average }\end{array}$} \\
\hline 1930 & (2) & 2.8 & & 2.8 & 2.4 & 94 & 6 & 3.6 & 1.5 & 0.6 & 10.7 & 4.8 & 2.2 & 1.4 & 2.1 & \\
\hline 1931 & (13) & 4.6 & 0.2 & 4.8 & 4.1 & 91 & 9 & 4.4 & 2.2 & 0.6 & 12.8 & 4.8 & 2.3 & 1.4 & 1.9 & 1.8 \\
\hline 1932 & (15) & 5.2 & 1.4 & 6.6 & 5.6 & 76 & 24 & 4.9 & 3.2 & 0.5 & 10.4 & 4.8 & 2.4 & 1.5 & 1.9 & 2.1 \\
\hline 1933 & (26) & 7.7 & 1.8 & 9.5 & 8.1 & 84 & 16 & 5.3 & 3.3 & 0.5 & 6.7 & 3.9 & 2.9 & 1.5 & 2.2 & 2.5 \\
\hline 1934 & (29) & 11.4 & 2.3 & 13.7 & 11.6 & 94 & 6 & 6.3 & 3.5 & 0.7 & 8.9 & 5.1 & 3.3 & 1.5 & 2.5 & 2.7 \\
\hline 1935 & (50) & 11.9 & 2.9 & 14.8 & 12.5 & 98 & 2 & 6.5 & 3.3 & 0.9 & 8.2 & 4.5 & 3.4 & 1.3 & 3.2 & 3.2 \\
\hline 1936 & (52) & 7.3 & 2.6 & 9.8 & 8.3 & 69 & 31 & 1.6 & 0.8 & 0.9 & 2.5 & 1.4 & 3.1 & 1.2 & 4.0 & 3.2 \\
\hline 1937 & (52) & 7.9 & 5.4 & 13.4 & 11.3 & 86 & 14 & 4.6 & 2.0 & 1.3 & 0.9 & 0.5 & 2.9 & 1.1 & 4.2 & 3.1 \\
\hline 1938 & (56) & 9.5 & 5.8 & 15.3 & 13.0 & 96 & 4 & 7.1 & 3.6 & 0.8 & 4.9 & 2.6 & 2.7 & 1.0 & 3.5 & 2.3 \\
\hline 1939 & (55) & 9.4 & 6.1 & 15.5 & 13.2 & 94 & 6 & 5.8 & 2.7 & 0.4 & 5.8 & 3.2 & 2.5 & 1.0 & 2.5 & 1.9 \\
\hline 1940 & (63) & 10.8 & 6.1 & 17.0 & 14.4 & 92 & 8 & 4.8 & 2.6 & 0.3 & 4.1 & 2.6 & 2.2 & 0.8 & 1.9 & 1.6 \\
\hline 1941 & & 8.8 & 8.8 & 17.6 & 14.9 & 93 & 7 & 4.8 & 3.4 & 0.3 & 5.6 & 3.0 & 2.0 & 0.8 & 1.8 & 1.5 \\
\hline 1942 & & 8.2 & 10.1 & 18.3 & 15.5 & 93 & 7 & 2.3 & 1.6 & 0.2 & 4.8 & 2.5 & & 0.9 & 1.6 & 1.7 \\
\hline 1943 & (68) & 5.8 & 13.3 & 19.0 & 16.1 & 93 & 7 & 0.1 & 0.1 & 0.3 & 4.9 & 3.2 & & 1.1 & 1.5 & 1.6 \\
\hline 1944 & (64) & 17.7 & 13.2 & 30.9 & 26.2 & 97 & 3 & 4.4 & 3.4 & 0.3 & & & & 1.1 & 1.3 & 1.4 \\
\hline 1945 & & 30.5 & 13.8 & 44.2 & 37.5 & 96 & 4 & 6.5 & 5.3 & 0.2 & & & & 1.0 & 1.1 & 1.1 \\
\hline
\end{tabular}


APPENDIX 1 (Cont.)

\begin{tabular}{|c|c|c|c|c|c|c|c|c|c|c|c|c|c|}
\hline 1946 & (75) & 49.5 & 14.1 & 63.6 & 53.9 & 94 & 6 & 5.9 & 4.5 & 0.2 & 1.0 & 0.9 & 1.0 \\
\hline 1947 & & & & & & & & 6.1 & 4.7 & 0.2 & 0.9 & 0.9 & \\
\hline 1948 & & & & & & & & 8.0 & 4.2 & 0.8 & 0.9 & 1.1 & \\
\hline 1949 & 55 & 24 & 31 & 55.6 & 31.9 & 55 & 45 & 7.3 & 3.4 & 1.0 & 0.9 & 1.3 & 2.3 \\
\hline 1950 & 59 & 28 & 41 & 69.0 & 43.5 & 65 & 35 & 10.0 & 4.0 & 1.3 & 0.9 & 1.4 & 2.2 \\
\hline 1951 & 62 & 21 & 53 & 73.6 & 50.2 & 65 & 35 & 9.7 & 3.0 & 2.0 & 0.9 & 1.4 & 2.3 \\
\hline 1952 & 63 & 30 & 48 & 78.4 & 57.1 & 66 & 34 & 15.7 & 4.5 & 2.0 & 0.9 & 1.4 & 2.7 \\
\hline 1953 & 65 & 44 & 40 & 83.6 & 64.1 & 69 & 31 & 6.6 & 2.8 & 0.7 & 1.2 & 1.7 & 3.2 \\
\hline 1954 & 67 & 38 & 47 & 84.9 & 65.1 & 69 & 31 & 8.3 & 4.7 & 0.6 & 1.6 & 1.8 & 3.8 \\
\hline 1955 & 69 & 28 & 58 & 86.3 & 67.6 & 68 & 32 & 10.4 & 6.0 & 0.5 & 2.3 & 1.8 & 3.9 \\
\hline 1956 & 70 & 42 & 50 & 92.1 & 73.4 & 66 & 34 & 13.4 & 7.8 & 0.5 & 2.4 & 2.0 & 4.0 \\
\hline 1957 & 72 & 30 & 74 & 103.2 & 84.3 & 68 & 32 & 15.3 & 8.9 & 0.4 & 2.6 & 2.1 & 3.9 \\
\hline 1958 & 73 & 40 & 77 & 117.5 & 99.2 & 70 & 30 & 21.2 & 11.2 & 0.5 & 2.4 & 2.2 & 3.8 \\
\hline 1959 & 75 & 46 & 81 & 126.9 & 106.0 & 70 & 30 & 19.4 & 11.2 & 0.5 & 2.5 & 2.0 & 3.7 \\
\hline 1960 & 79 & 47 & 89 & 136.6 & 115.1 & 69 & 31 & 18.7 & 7.6 & 1.1 & & 1.9 & 3.6 \\
\hline 1961 & 77 & 48 & 103 & 150.9 & 130.2 & 72 & 28 & 10.0 & 6.9 & 0.2 & & 1.9 & 3.6 \\
\hline 1962 & 97 & 56 & 178 & 206.7 & 181.0 & 71 & 29 & 13.7 & 8.8 & 0.3 & & 1.6 & 3.5 \\
\hline 1963 & 101 & 57 & 237 & 255.7 & 229.7 & 74 & 26 & 11.3 & 6.9 & 0.4 & & 1.6 & 3.4 \\
\hline 1964 & 104 & 42 & 283 & 294.4 & 262.6 & 75 & 25 & 5.1 & 3.7 & 0.3 & & 1.7 & 3.3 \\
\hline 1965 & 110 & 61 & 319 & 340.7 & 305.0 & 75 & 25 & 1.2 & 1.0 & 0.2 & & 1.8 & 3.1 \\
\hline 1966 & 116 & 75 & 374 & 407.7 & 371.5 & 76 & 24 & 1.4 & 1.1 & 0.2 & & 1.8 & 3.0 \\
\hline 1967 & 121 & 57 & 466 & 488.0 & 448.0 & 76 & 24 & 0.7 & 0.6 & 0.2 & & & \\
\hline
\end{tabular}


APPENDIX 1 (Cont.)

\begin{tabular}{|c|c|c|c|c|c|c|c|c|c|c|c|c|c|c|c|c|}
\hline \multirow{2}{*}{ Year } & \multirow[t]{3}{*}{ Clients } & \multicolumn{3}{|c|}{ Production } & \multicolumn{3}{|c|}{ Consumption } & \multicolumn{5}{|c|}{ Economic financial ratios } & \multicolumn{4}{|c|}{ Real unit cost } \\
\hline & & \multirow[b]{2}{*}{ Own } & \multirow[b]{2}{*}{ Acquired } & \multirow[b]{2}{*}{ Distributed } & \multirow[b]{2}{*}{ Total } & \multirow[b]{2}{*}{ Industrial } & \multirow[b]{2}{*}{ Domestic } & \multicolumn{3}{|c|}{ Fensa } & \multicolumn{2}{|c|}{ Ibérica } & \multirow[b]{2}{*}{ Arteta } & \multirow[b]{2}{*}{ Irati } & \multirow[b]{2}{*}{ Ibérica } & \multirow[b]{2}{*}{ Fensa } \\
\hline & & & & & & & & ROE & ROA & Debt & ROE & ROA & & & & \\
\hline & $\begin{array}{l}\text { No. from } 1949 \\
\text { (thousands) }\end{array}$ & \multicolumn{3}{|c|}{ GWh } & GWh & \multicolumn{2}{|c|}{$\%$} & \multicolumn{2}{|c|}{$\%$} & ppu & \multicolumn{2}{|c|}{$\%$} & \multicolumn{4}{|c|}{$\begin{array}{c}\text { Cents/kWh @ } 1913 \text { value } \\
3 \text { year average }\end{array}$} \\
\hline 1968 & 132 & 65 & 527 & 551.7 & 510.3 & 74 & 25 & 0.5 & 0.4 & 0.2 & & & & & & \\
\hline 1969 & 139 & 69 & 639 & 670.2 & 623.1 & 74 & 26 & 0.0 & 0.0 & 0.3 & & & & & & \\
\hline 1970 & 147 & 64 & 723 & 753.1 & 709.0 & 73 & 27 & 0.0 & 0.0 & 0.4 & & & & & & \\
\hline 1971 & 193 & 63 & 819 & 843.9 & 786.3 & 72 & 28 & 0.0 & 0.0 & 0.6 & & & & & & \\
\hline 1972 & 208 & 85 & 924 & 970.2 & 889.3 & 73 & 27 & 1.3 & 0.8 & 0.5 & & & & & & \\
\hline 1973 & 210 & 67 & 1,049 & $1,081.9$ & $1,014.4$ & 72 & 28 & 2.0 & 1.1 & 0.5 & & & & & & \\
\hline 1974 & 211 & 69 & 1,135 & $1,166.6$ & $1,115.8$ & 71 & 30 & 1.4 & 0.9 & 0.6 & & & & & & \\
\hline 1975 & 213 & 75 & 1,180 & $1,222.6$ & $1,138.2$ & 68 & 32 & 0.0 & 0.0 & 0.5 & & & & & & \\
\hline 1976 & 214 & 59 & 1,343 & $1,356.1$ & $1,285.0$ & 67 & 33 & 0.0 & 0.0 & 0.6 & & & & & & \\
\hline 1977 & 216 & 68 & 1,450 & $1,463.7$ & $1,387.8$ & 67 & 33 & 0.0 & 0.0 & 0.8 & & & & & & \\
\hline 1978 & 228 & 70 & 1,544 & $1,570.0$ & $1,484.9$ & 66 & 34 & 0.0 & 0.0 & 0.4 & & & & & & \\
\hline 1979 & 244 & 72 & 1,676 & $1,698.5$ & $1,623.0$ & 64 & 36 & 0.1 & 0.1 & 0.3 & & & & & & \\
\hline 1980 & 243 & 65 & 1,761 & $1,775.0$ & $1,717.1$ & 63 & 37 & 0.1 & 0.1 & 0.3 & & & & & & \\
\hline
\end{tabular}

ROA: return on assets; ROE: return on equity; ROS: return on sales.

Source: Own compilation from consulting monthly entries in the General Ledgers of Fensa (1927-1946), Annual Reports of Fensa (1930-1946); Annual Reports of Arteta (1930-1941), Annual Reports of Irati (1930-1959) and Annual Reports of Hidroeléctrica Ibérica/Iberduero (1930-1966).

Key: Real unit cost: total cost/kWh sold; ROA: income before tax/total assets; ROE: income before tax/shareholders' equity; ROS: income before tax/sales; Debt ratio: external financing/ self-financing (share capital + reserves). *Industrial clients in parenthesis. 
APPENDIX 2

ECONOMIC AND FINANCIAL DATA (1930-1980)

\begin{tabular}{|c|c|c|c|c|c|c|c|c|c|c|}
\hline & \multicolumn{6}{|c|}{ Fensa } & Ibérica & Hidrola & Irati & Arteta \\
\hline \multirow[t]{3}{*}{ Year } & $\begin{array}{l}\text { Equity } \\
\text { capital }\end{array}$ & Bonds & Profits & Sales & $\begin{array}{l}\text { Distribution of } \\
\text { dividends }\end{array}$ & & & & & \\
\hline & & & & & Board of directors & Shareholders & & & & \\
\hline & \multicolumn{4}{|c|}{$10^{3}$ thousand pesetas } & $\%$ profits & Dividend yield & Dividends & Dividends & Dividends & Dividends \\
\hline 1930 & 3,998 & 1,939 & 0,143 & 0,211 & & & 9 & 10 & 10 & 9.5 \\
\hline 1931 & 4,977 & 1,979 & 0,217 & 0,347 & 10 & 5 & 9 & 10 & 11 & 10 \\
\hline 1932 & 6,011 & 1,979 & 0,296 & 0,519 & 9 & 5 & 9 & 9 & 10 & 10 \\
\hline 1933 & 6,025 & 1,979 & 0,317 & 0,744 & 10 & 4 & 8.5 & 9 & 8.8 & 10 \\
\hline 1934 & 6,040 & 4,134 & 0,379 & 1,066 & 10 & 5 & 8.5 & 9 & 9.0 & 10 \\
\hline 1935 & 6,059 & 4,251 & 0,392 & 1,082 & 9 & 5 & 8 & 9 & 9.5 & 10 \\
\hline 1936 & 6,078 & 4,206 & 0,099 & 0,785 & & & & 4.5 & 4.8 & 10 \\
\hline 1937 & 6,078 & 5,158 & 0,280 & 1,020 & 9 & 3 & & 5.5 & 4.8 & 10 \\
\hline 1938 & 6,091 & 4,086 & 0,435 & 1,145 & 10 & 5 & 8 & 5 & 6.0 & 10 \\
\hline 1939 & 7,832 & 4,052 & 0,454 & 1,207 & 13 & 5 & 6 & 5 & 8.9 & 12 \\
\hline 1940 & 14,097 & 3,864 & 0,678 & 1,258 & 12 & 7 & 7 & 8 & 11.4 & 5 \\
\hline 1941 & 20,012 & 3,591 & 0,958 & 1,540 & 13 & 5 & 7 & 8 & 11.8 & 10 \\
\hline 1942 & 25,207 & 3,475 & 0,580 & 1,587 & 12 & 2 & 6 & 8 & 7.0 & 10 \\
\hline 1943 & 25,244 & 3,272 & 0,024 & 1,480 & & & 6 & 8 & 8.7 & 5 \\
\hline 1944 & 30,244 & 3,203 & 1,344 & 2,352 & 10 & 4 & 6 & 8 & 8.7 & 10 \\
\hline
\end{tabular}


APPENDIX 2 (Cont.)

\begin{tabular}{|c|c|c|c|c|c|c|c|c|c|c|}
\hline & \multicolumn{6}{|c|}{ Fensa } & \multirow[t]{2}{*}{ Ibérica } & \multirow[t]{2}{*}{ Hidrola } & \multirow[t]{2}{*}{ Irati } & \multirow[t]{2}{*}{ Arteta } \\
\hline Year & $\begin{array}{l}\text { Equity } \\
\text { capital }\end{array}$ & Bonds & Profits & Sales & $\begin{array}{l}\text { Distribution of } \\
\text { dividends }\end{array}$ & & & & & \\
\hline & & & & & Board of directors & Shareholders & & & & \\
\hline & \multicolumn{4}{|c|}{$10^{3}$ thousand pesetas } & $\%$ profits & Dividend yield & Dividends & Dividends & Dividends & Dividends \\
\hline 1945 & 30,298 & 2,863 & 1,973 & 3,078 & 10 & 4 & 5 & 7 & 8.7 & 10 \\
\hline 1946 & 30,448 & 1,900 & 1,810 & 4,309 & 5 & 4 & 6 & 8 & 8.0 & 10 \\
\hline 1947 & 30,598 & 1,732 & 1,861 & 4,539 & 5 & 4 & 6.5 & 9 & 8.3 & 10 \\
\hline 1948 & 30,598 & 18,568 & 2,459 & 10,704 & 4 & 4 & 7 & 10 & 8.9 & 10 \\
\hline 1949 & 30,598 & 18,892 & 2,244 & 12,383 & 5 & 4 & 7 & 10 & 8.8 & 10 \\
\hline 1950 & 30,598 & 23,390 & 3,055 & 17,622 & 5 & 4 & 8.5 & 10 & 8.5 & 10 \\
\hline 1951 & 30,598 & 19,504 & 2,964 & 19,663 & 5 & 4 & 9.5 & 10 & 8.4 & 10 \\
\hline 1952 & 30,598 & 19,217 & 4,811 & 22,518 & 4 & 4 & 10 & 10 & 9.4 & 9 \\
\hline 1953 & 45,888 & 18,645 & 3,048 & 33,008 & & 7 & 11 & 10 & 9.4 & 10 \\
\hline 1954 & 58,823 & 18,337 & 4,897 & 36,931 & & 7 & 11 & 10 & 8.4 & 10 \\
\hline 1955 & 60,541 & 17,677 & 6,301 & 43,688 & & 7 & 11 & 12 & 8.4 & 10 \\
\hline 1956 & 62,767 & 16,974 & 8,423 & 48,656 & & 8 & 12 & 12 & 9.5 & \\
\hline 1957 & 66,602 & 16,245 & 10,163 & 62,412 & & 8 & 12 & 12 & 9.5 & \\
\hline 1958 & 72,139 & 15,500 & 15,259 & 79,345 & & 8 & 12 & 12 & 8.7 & \\
\hline 1959 & 85,740 & 14,908 & 16,629 & 83,874 & & 8 & 12 & 12 & 9.6 & \\
\hline 1960 & 97,569 & 13,849 & 18,265 & 90,476 & & 8 & 12 & 12 & 9.2 & \\
\hline 1961 & 193,699 & 13,359 & 19,291 & 98,628 & & 8 & 12 & 12 & & \\
\hline 1962 & 208,148 & 12,853 & 28,461 & 139,885 & & 8 & 12 & 12 & & \\
\hline
\end{tabular}


APPENDIX 2 (Cont.)

\begin{tabular}{|c|c|c|c|c|c|c|c|}
\hline 1963 & 225,409 & 12,321 & 25,510 & 172,843 & 6 & 12 & 12 \\
\hline 1964 & 272,990 & 11,767 & 14,046 & 195,332 & 4 & 12 & 12 \\
\hline 1965 & 642,327 & 11,184 & 7,629 & 220,156 & 4 & 12 & 12 \\
\hline 1966 & 643,532 & 10,567 & 8,758 & 262,999 & 4 & 12 & 12 \\
\hline 1967 & 824,845 & 9,913 & 5,656 & 314,927 & & & \\
\hline 1968 & 807,576 & 9,238 & 4,025 & 364,215 & & & \\
\hline 1969 & 811,601 & 8,564 & 0 & 435,635 & & & \\
\hline 1970 & 811,313 & 7,820 & 0 & 498,752 & & & \\
\hline 1971 & 811,229 & 7,034 & 0 & 610,252 & & & \\
\hline 1972 & 971,229 & 166,221 & 13,041 & 687,693 & & & \\
\hline 1973 & 984,200 & 165,368 & 19,194 & $1,208,865$ & & & \\
\hline 1974 & $1,186,933$ & 164,463 & 17,060 & $1,865,354$ & & & \\
\hline 1975 & $2,003,127$ & 155,816 & 0 & $2,352,654$ & & & \\
\hline 1976 & $2,004,503$ & 146,883 & 0 & $3,079,450$ & & & \\
\hline 1977 & $2,004,503$ & 137,118 & 0 & $3,736,621$ & & & \\
\hline 1978 & $3,022,523$ & 126,298 & 0 & $4,349,019$ & & & \\
\hline 1979 & $5,355,706$ & 116,429 & 7,519 & $5,182,181$ & & & \\
\hline 1980 & $6,998,798$ & 105,165 & 7,661 & $7,297,497$ & & & \\
\hline
\end{tabular}

Source: see Appendix 1 and Antolín (2006), Aubanell (2006), Gómez Mendoza (2006) and Sudrià (2006) in relation to the dividends of Ibérica and Hidrola.

Key: Dividend yield: annual dividends per share/price per share; Equity capital: share capital and reserves. 